\title{
Huzurevi Sakinlerinin Huzurevi Bahçelerinden Duyduklari Çevresel Memnuniyet Düzeyleri; Doğu Karadeniz Bölgesi Örneği
}

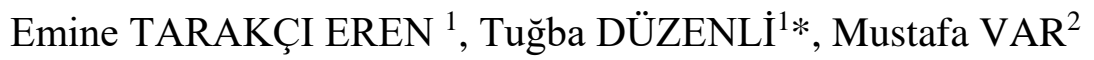 \\ ${ }^{1}$ Karadeniz Technical University, Faculty of Forestry, DepLandscape Architecture, 61080, TRABZON \\ ${ }^{2}$ Yıldız Technical University, Faculty of Architecture, City Reginonal and Planning, 34349, ISTANBUL
}

Öz

Yaşlı kişilerin, huzurlu bir çevrede yaşantılarını devam ettirmesi fiziksel ve ruhsal açıdan iyi olmalarına bağlıdır. Yaşadıkları kurum ve bahçesinden memnuniyetlerinin artması, yalnızlıklarının azalması, aidiyet duygularının gelişmesi, sosyal ilişki ve günlük aktivite düzeylerinin yükselmesi için huzurevi bahçeleri tasarımlarının başarılı ve yeterli olması gerekmektedir. Bu nedenle araştırmada, huzurevi bahçelerinden duyulan memnuniyet düzeyinin peyzaj elemanları ve fiziksel çevre özellikleri ile ilişkisi araştırılmıştır. Çalışmada, huzurevi bahçelerinde kurum sakinlerinin çevresel memnuniyet düzeylerini belirlemek amacıyla; üç aşamalı bir araştırma yöntemi geliştirilmiştir. 1. ve 2. aşamasında çalışma alanı ve örneklem seçilmiştir. Buna göre Doğu Karadeniz Bölgesi'ndeki huzurevlerinden, 7 tanesi belirlenmiştir. Belirlenen bu yedi huzurevi sakinleri arasından tabakalı ve rastlantısal örnekleme ile 130 katılımcı seçilmiştir. 3. aşamada ise, huzurevi sakinlerinin kurum bahçelerinden duydukları memnuniyet düzeyi belirlenmeye çalışılmıştır. Her bir huzurevi bahçesinin fiziksel özelliklerine bağlı olarak, çevresel memnuniyet düzeyleri de farklılık göstermiştir. Çalışmanın sonucunda huzurevi sakinlerinin değerlendirmelerine bağlı olarak; çevresel memnuniyet düzeyini etkileyen fiziksel özellikler; konumsal özellikler, erişilebilirlik özellikleri ve tasarım özellikleri tespit edilmiştir. Bunların içerisinden çevresel memnuniyet düzeyine en çok etki eden fiziksel özellik ise erişilebilirlik özelliği çıkmıştır. Huzurevlerinin ulaşım farklarından dolayı; erişilebilirlik özelliğinden duyulan memnuniyet düzeyleri de farklılık göstermiştir

Anahtar Kelimeler: Yaşlılık sorunları, peyzaj tasarımı, kullanıcı memnuniyeti.

\section{Environmental Satısfactıon Levels Of Elder People From Nursıng Homes: Example Of Eastern Black Sea Region}

\begin{abstract}
The aim of the study is to investigate the design and landscape elements of open green spaces, the improvement of daily life and the increase in the satisfaction of the old people, the satisfaction of their institutions and gardens, the increase of their loneliness, the development of their social relations and the increase in their daily activities. In the study, in order to determine the environmental satisfaction levels of nursing homes; 3stage research method has been developed. In the first and second stage, the study area and sample selection were made. 7 nursing homes were selected from the nursing homes in the Eastern Black Sea Region. 130 participants were selected by stratified and random sampling. In the third stage, the level of satisfaction of nursing home residents in was tried to be determined. It is determined that the level of environmental satisfaction of each nursing home environment in their homes depends on the physical characteristics. Environmental satisfaction levels and environmental preference levels will increase if these expectations of nursing home residents are met when the institutional gardens are designed. As a result, depending on the evaluation of the residents of the nursing home; physical characteristics affecting the level of environmental satisfaction. Among them, physical property which has the most effect on environmental satisfaction level has accessibility feature. In addition, since the accessibility characteristics of each nursing home differed, it was determined that the satisfaction levels of the institutions' accessibility characteristics differed.
\end{abstract}

Keywords: Elderly problems, landscape design, user satisfaction.

\footnotetext{
*Sorumlu Yazar (Corresponding Author):

Tuğba Düzenli (Doç.Dr.); Karadeniz Technical University, Faculty of

Forestry, Landscape Architecture, 61080, TRABZON, Turkey. Tel: +90 (462)

37740 53, E-mail: tugbaduzenli@gmail.com, ORCID:0000-0001-6957-3921

Geliş (Received) : 04.02.2019

Kabul (Accepted) : 08.04.2019

Basım (Published) : 15.08.2019
} 


\section{Giriş}

Tüm dünyada ve ülkemizde yaşlı nüfusta gözlenen artış sosyal refahın ve yaşlıya sunulan hizmetlerin artması gerekliliğini ortaya koymuştur. Kentleşme olgusu; geniş ailenin çekirdek aileye dönüşmesine, kırsal bölgelerden kentsel bölgelere göçe, kadının çalışma hayatına girmesine, geleneksel kültür ve değerlerdeki değişmelere ve sonuç olarak yaşlının aile içindeki eski rolünü yitirmesine neden olmuştur. Yaş saygınlık sağlayan bir öğe olmaktan çıkmıştır. Kuşaklar arasındaki farklılıklar nedeniyle de normal şartlarda ailelerin üstlenmesi gereken yaşlılara bakım görevini, toplum üstlenmiştir. Çözüm olarak bireylerin yaşam standartlarını korumayı ve yükseltmeyi amaçlayan hizmetlerin tümünü içeren huzurevleri (ya da bakım-rehabilitasyon merkezleri ve yaşlı hizmet merkezlerinin) açılmasına ihtiyaç duyulmuştur (URL-1).

Yaşlılar üzerine yapılan çalışmaların çoğunun sosyoloji, psikoloji, sosyal hizmetler, ev ekonomisi, geriatri, halk sağlığı, hemşirelik vb. alanlarda olduğu tespit edilmiştir. Mekânsal açıdan yaşlıların beklentilerini araştıran çalışmalar da genellikle mimari ya da iç mimari alanındadır (Sarı ve Sağsöz, 2011). Peyzaj mimarlığı açısından bu konuya ilişkin araştırmaların çok fazla olmadığı görülmüştür (Eren 2016; Eren vd, 2017; Eren vd, 2018). Açık veya yeşil alanın mekânsal nitelik-niceliklerinin insanlar üzerindeki olumlu ya da olumsuz etkileri pek çok çalışmaya konu olmuştur (Düzenli ve Alpak, 2017). Ancak huzurevlerinin açık mekân ve çevrelerinin yaşlıların sosyal, psikolojik ve fiziksel ihtiyaçlarına bağlı olarak yeterli olup olmadığı konusunda araştırmalar eksiktir. Huzurevi bahçelerinin kullanıcılar üzerindeki etkisi, beklentilerini karşılamakta yeterli olup olmadıkları, kuruluş amaçlarına ne kadar hizmet ettiklerine yönelik kapsamlı çalışmaların yapılmadığı görülmüştür. Bu açıdan bu konudaki eksikliklerden hareketle bu makalede Doğu Karadeniz Bölgesi'nde bulunan Aile ve Sosyal Politikalar Bakanlığı'na bağlı huzurevlerinin peyzaj elemanları ve tasarımları yerinde incelenmiştir. Tamamıyla yaşlılara özgü mekânlar olan huzurevleri ve açık mekânları, çalışma alanı olarak belirlenmiştir.

“Türk yaşlısının yaşamını zorlaştıran nedenlerden biri de yaşlılığın koşullarına uygun bir çevrede yaşamaması ve yaşlıları dikkate alan bir yeşil alan düzenlemesinin bulunmamasıdır. Türkiye'deki binaların birçoğu, yaşlıları ve engellileri dikkate alarak inşâ edilmemiştir. Sokaklar, caddeler, meydanlar, parklar ve diğer açık ve yeşil alanlar da aynı şekildedir. Yaşlıların bedensel ve sosyal ihtiyaçları göz önünde bulundurularak tasarlanan binaların çevresi, onların günlük ihtiyaçlarını rahatça karşılamalarına yardımcı ve destek olmalıdır. Kendilerini sosyal yaşamdan soyutlayan binalarda ve çevrelerde yaşayan yaşlılara, sokaklarda pek rastlanamamasının nedenlerinden biri de budur'(Tufan, 2003).

\subsection{Yaşlılık Döneminde Çevresel Memnuniyet}

Peyzaj ile ilgili memnuniyet ve değerlendirme, çevrenin fiziksel özellikleri ile bireysel tepkileri içeren nesneözne etkileşiminde gerçekleşen bir olgudur (Pikora vd., 2003; Tekel ve Özalp, 2016; Kutay vd., 2016). Bir başka deyişle çevre ve açık mekanların bir takım ölçütleri ne oranda karşıladığının sorgulanmasıdır. Bu ölçütler ise birey ve çevreye ait olmak üzere ikiye ayrılır. Bireye ait olanlar sosyo-demografik özellikler ile zihinsel (algısal ve bilişsel süreçleri) süreçlerdir. Çevreye ait olanlar ise fiziksel, biçimsel/estetik ve işlevsel/fonksiyonel ölçütlerdir. Çevresel memnuniyet, bireyin zihinsel özellikleri ile çevrenin ölçülebilir fiziksel özelliklerini değerlendirmesidir. Bireyin çevresini değerlendirmesiyle çevresinden duyduğu memnuniyeti ölçmek mümkün olmaktadır (Bonnes ve Bonaiuto, 1995; Ibem vd., 2013). Memnuniyet düzeyi, mevcut fiziksel ve sosyal koşullardan bireyin zihinsel süreçleri arasındaki uyumdan etkilenmektedir (Canter, 2000; Preiser ve Vischer, 2005; Amerigo ve Aragones, 1997; Manzo ve Perkins, 2006; Evans vd., 2002; Schaefer-McDaniel vd, 2010; Schootman vd., 2007; Spokane vd., 2007; Adriaanse, 2007; Bonaiuto vd., 1999; Galster ve Hesser, 1981; Handal vd., 1981; Austin vd., 2002; Coley vd., 1997). Bu bağlamda bu araştırmada huzurevi bahçelerinden duyulan memnuniyet düzeylerinin belirlenmesine yönelik bir model geliştirilmiştir. $\mathrm{Bu}$ modelde çevresel memnuniyeti etkileyen faktörler şunlardır:

- Bireyin demografik ve zihinsel özellikleri

- Çevrenin fiziksel özellikleri (Evans vd., 2002; Spokane vd., 2007; Handal vd., 1981; Wright ve Kloos, 2016) (Şekil 1)

Bu çalışma kapsamında çevresel memnuniyeti etkileyen iki önemli faktör olarak belirlenen çevre ve birey; birbirinden soyutlanamamıştır. Bunun nedeni, bireyin fiziksel çevresiyle karşılıklı olarak sürekli ilişki içinde olmasıdır. Bireyin özellikleri, etkinlikleri, ihtiyaçları, beklentileri, davranışları ve (algılama+biliş) zihinsel süreçleri çevreyle sürekli bir ilişki içindedir. 


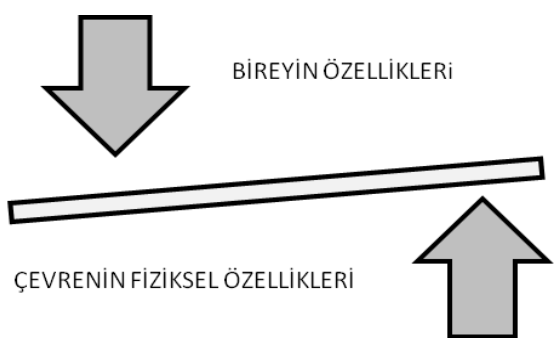

Şekil 1. Çevresel memnuniyet düzeyinin belirlenmesi ile ilgili geliştirilen çatkı

$\mathrm{Bu}$ çalışmada; yaşlı kişilerin, huzurlu bir çevrede yaşantılarını devam ettirmesi fiziksel ve ruhsal açıdan iyi olmaları, yaşadıkları kurum ve bahçesinden memnuniyetlerinin artması, yalnızlıklarının azalması, aidiyet duygularının artması, sosyal ilişkilerinin geliştirilmesi ve günlük aktivitelerinin artmasına katkı sağlaması açısından huzurevi bahçelerinin, açık yeşil alanların tasarımları ve peyzaj elemanları araştırılmıştır.

Bir huzurevi verdiği barınma, bakım ve sağlık hizmeti ile etkin olduğu kadar, iyi tasarlanmış bahçesi ile de, kullanıcısı ve bulunduğu kentsel çevre için etkin olabilmektedir. Huzurevi bahçeleri uygun peyzaj tasarımları ile kullanıcılarının gereksinimini karşılayan dış mekânlar olarak değerlendirilmelidirler. Çalışmanın da amacı huzurevi bahçelerinin peyzaj tasarımlarını değerlendirerek, kullanıcı memnuniyet düzeylerini ortaya koymaktır.

\section{Materyal ve Metot}

$\mathrm{Bu}$ çalışmanın ana materyalini; huzurevi bahçelerinin peyzaj tasarımları değerlendirilerek, mevcut durumlarının belirlenmesi aynı zamanda huzurevi sakinlerinin bu koşullardan duydukları çevresel memnuniyet düzeylerinin saptanması amacıyla Doğu Karadeniz Bölgesi'nde yer alan 7 huzurevi bahçesi oluşturmaktadır (Tablo 1). Huzurevi bahçelerinin çevresel özellikleri ve huzurevi sakinlerine uygulanan çevresel memnuniyeti ölçmek için kullanılan anket formu ise çalışmanın yardımcı materyalini oluşturmaktadır. Bu araştırmanın, aşağıda belirtilen aşamaları kapsaması planlanmıştır.

- Birinci aşama, çalışma alanı seçimi

- İkinci aşama, örneklem seçimi

- Üçüncü aşama, çevresel memnuniyet düzeyinin belirlenmesi

Aşamaların detayları bundan sonraki kısımda açıklanmıştır.

\subsection{Aşama 1- Çalışma Alanının Seçilmesi Ve Tanımlanması}

$\mathrm{Bu}$ çalışmanın Doğu Karadeniz Bölgesi'nde bulunan huzurevlerinde yapılması hedeflenmiş̧tir. Seçilen huzurevlerinin Aile ve Sosyal Politikalar Bakanlığı (ASPK), Engelli ve Yaşlı Hizmetleri Genel Müdürlüğü'ne bağlı olması şartı aranmıştır. Bunun nedeni ilgili bakanlığın en yetkili mercii olması ve en fazla sayıda huzurevini ve dolayısıyla da en fazla kullanıcı sayısını bünyesinde barındırmasıdır. Ayrıca hizmet özelliği açısından huzurevi olması şartı da aranmıştır (Tablo 1).

Tablo 1. Araştırma kapsamında ele alınan huzurevleri.

\begin{tabular}{cclccc}
\hline Kod & İli & \multicolumn{1}{c}{ Huzurevi adı } & Mevcut & $\begin{array}{c}\text { Normal } \\
\text { bakım }\end{array}$ & Özel bakım \\
\hline $\mathbf{1}$ & Artvin & Artvin Naime-Ismail Yilmaz Huzurevi & 32 & 21 & 11 \\
$\mathbf{2}$ & Artvin & Artvin Murgul Huzurevi & 40 & 28 & 12 \\
$\mathbf{3}$ & Giresun & Giresun Huzurevi Yaşlı Bakım Ve R.M. & 72 & 44 & 27 \\
$\mathbf{4}$ & Ordu & Ordu Ahmet Cemal Mağden Huzurevi & 157 & 135 & 22 \\
$\mathbf{5}$ & Rize & Fındılı Huzurevi Yaşı Bakım ve R.M. & 52 & 22 & 30 \\
$\mathbf{6}$ & Trabzon & Trabzon Huzurevi Yaşlı Bakım Ve R.M. & 170 & 23 & 147 \\
$\mathbf{7}$ & Trabzon & Trabzon Köşk Huzurevi & 73 & 67 & 6 \\
\hline & Toplam & & 596 & 340 & 256 \\
\hline
\end{tabular}




\subsection{Aşama 2- Örneklem Seçimi}

Makale çalışması kapsamında kullanılan örnekleme yöntemi rastlantısal ve tabakalı örnekleme yöntemidir. Tabakalı örneklemin belirlenmesinde cinsiyet faktörü baz alınmıştır. Örneklem büyüklüğünü saptamada aşağıdaki formül (Baş, 2006) kullanılarak toplam örneklem büyüklüğü hesaplanmıştır.

N: Toplam huzurevi kapasitesi 596 (20 Eylül 2017 tarihli kurumların kendilerinden elde edilen verilerden).

Z: Güvenirlilik düzeyi (\%99 güvenirlilik=2,58)

P: Olayın gerçekleşme olasılığ $1(0,5)$

Q: Olayın gerçekleşmeme olasılı̆̆ $1(1-0,5=0,5)$

D: Kabul edilen hata payı $(\% 10$ hata pay $1=0,1)$

n: Örneklem sayısı

$$
\begin{gathered}
\mathrm{n}=\frac{\mathrm{Z}^{2} \times \mathrm{N} \times \mathrm{P} \times \mathrm{Q}}{(\mathrm{N}-1) \times \mathrm{D}^{2}+\mathrm{Z}^{2} \times \mathrm{P} \times \mathrm{Q}} \\
\mathrm{n}=\frac{2,58^{2} \times 596 \times 0,5}{(596-1) \times 0,1^{2}+2,58^{2} \times 0,5 \times 0,5}=130
\end{gathered}
$$

Huzurevi bazında örneklem büyüklüğü, yine 20 Eylül 2017 tarihli kurumların kendilerinden elde edilen verilerden huzurevi kapasiteleri baz alınarak (Tablo 2), aşă̆ıda belirtilen formül ile belirlenmiştir.

N: Toplam huzurevi kapasitesi (596)

n: örneklem sayısı (130)

$\mathrm{N}$ il: İldeki toplam huzurevi kapasitesi

$\mathrm{n}$ il: ildeki örneklem sayısı

$$
\mathrm{n} \text { il }=\frac{\mathrm{n} \times \mathrm{N} \text { il }}{\mathrm{N}}
$$

Üçüncü aşamada kullanılacak anket tekniği için denek sayısı her il için yukarıdaki formülle hesaplanmıştır. Bu anket sağlıklı yaşlılarla yapılmış, akıl ve ruh sağlığı problemi olan, bağımlı, demansı yüksek, iletişim sorunu olan, işitme sorunu olan ve ankete katılmak istemeyen yaşlılar elimine edilmiştir.

Tablo 2. İllere Göre (Örneklem Büyüklüğü)

\begin{tabular}{lcll}
\hline İL & KAPASiTE & N & $(\mathbf{Z}=\% 99, \mathbf{D = \% 1 0 )}$ \\
\hline Artvin & 72 & 15 & \\
Giresun & 72 & 15 & \\
Ordu & 157 & 35 & \\
Rize & 52 & 12 & \\
Trabzon & 243 & 53 & \\
\hline Toplam Huzurevi:7 & 596 & 130 & \\
\hline
\end{tabular}

\subsection{Aşama 3- Çevresel Memnuniyet Düzeyinin Belirlenmesi}

$\mathrm{Bu}$ aşama iki adımda gerçekleştirilmiştir. Birinci adımda, huzurevi ve bahçelerine ait fiziksel özellikler araştırmacı tarafından yerinde gözlem çalışmaları yapılarak şema, fotoğraf ve tablolar aracılığıyla ortaya koyulmuştur. İkinci adımda tespit edilen bu özelliklerden huzurevi sakinlerinin duydukları memnuniyet düzeyleri anket tekniği kullanılarak tespit edilmiştir. Huzurevi bahçelerinin fiziksel özelliklerinin yeterlilikleri, karşılanması ya da karşılanmaması durumunda farklı çevresel memnuniyet düzeyleri ortaya çıkmaktadır. Dolayısıyla hangi fiziksel özelliklerin, mekânlarda memnuniyet düzeylerini etkilediğini belirlemek amacıyla anket yöntemi kullanılmıştır. Çevresel memnuniyet düzeylerinin belirlenmesinde etkili olan bahçelerin mevcut fiziksel özellikleri literatür taraması, arazi gözlemleri ve kurum ziyaretleri ile saptanmış çevrelerine ilişkin duydukları memnuniyet düzeylerini belirlemeyi amaçlayan ifadelerde likert tutum skalası ile sorgulanmıştır. Anket çalışması yüz yüze anket tekniği kullanılarak; huzurevine ait bahçe, oda, toplantı salonu ve çay odası gibi 
bölümlerde gerçekleştirilmiştir.

\section{Bulgular ve Tartışma}

\subsection{Aşama 1 e İlişkin Bulgular}

Huzurevi bahçelerinde incelemeler yapılmış, mevcut duruma ilişkin bulgular elde edilmiştir. Huzurevi bahçelerine ait peyzaj projeleri kurumlardan elde edilememiş̧ir. Bu nedenle çıkarılan plan şemaları, yerleşim planları yerinde gözlem çalışmaları yapılarak çizilmiştir. Yakın komşuluk ilişkileri, bahçelerdeki mekânsal bileşenler (yapısal ve bitkisel) belirlenmiştir.

Huzurevlerine ilişkin yapılan yerinde incelemeler sonucundaki değerlendirmeler tablolara aktarılmışıtır. Buna göre, huzurevlerine ilişkin bilgiler; Artvin Naime İsmail Yılmaz Huzurevi Tablo 3, Artvin Murgul Huzurevi Tablo 4, Giresun Huzurevine Tablo 5, Ordu Ahmet Cemal Mağden Huzurevi Tablo 6, Rize Findıklı Huzurevi Tablo 7, Trabzon Çamlık Huzurevi Tablo 8, Trabzon Köşk Huzurevi Tablo 9'da anlatılmıştır.

Tablo 3. Artvin Naime İsmail Yılmaz Huzurevi Özellikleri (Eren, 2018)

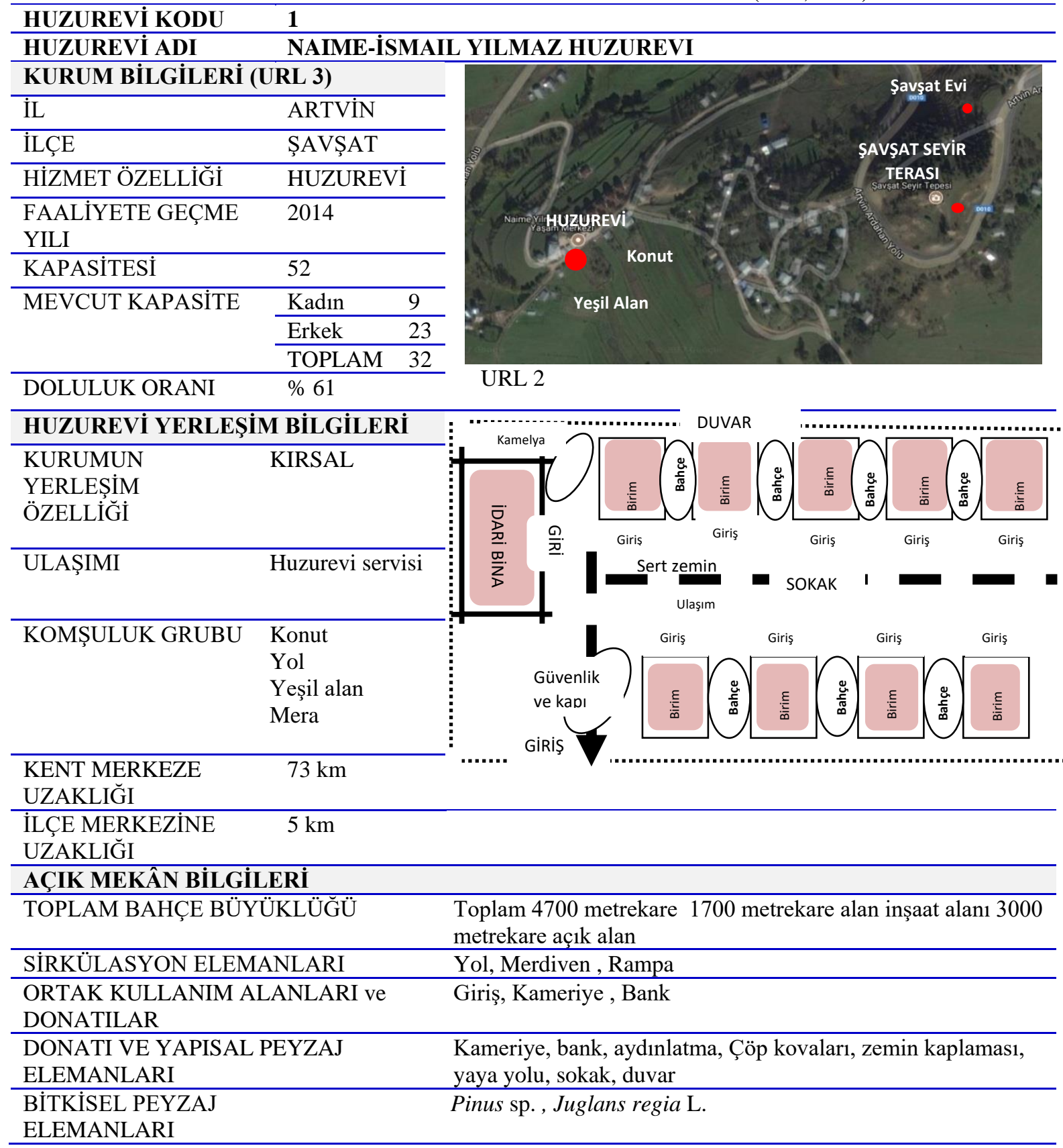


Tablo 4. Artvin Murgul Huzurevi Özellikleri (Eren, 2018)

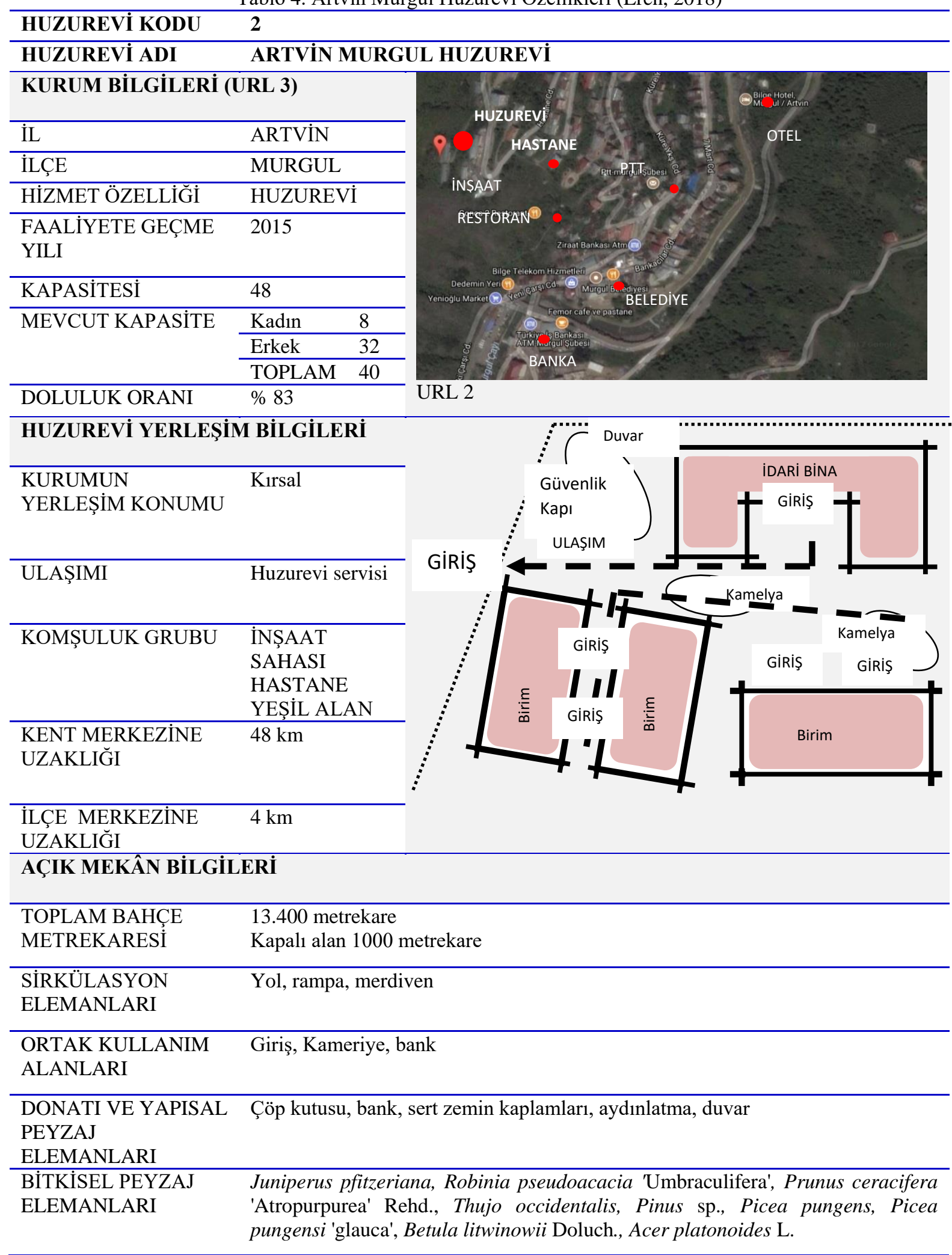


Tablo 5. Giresun Huzurevi Özellikleri (Eren, 2018)

\begin{tabular}{|c|c|c|}
\hline HUZUREVİ KODU & 3 & \\
\hline HUZUREVİ ADI & Giresun $\mathrm{Hu}$ & zurevi \\
\hline KURUM BİLGİLER & (URL 3) & \\
\hline İL & Giresun & \\
\hline İLÇE & Merkez & \\
\hline HİZMET ÖZELLİĞİ & Huzurevi & \\
\hline $\begin{array}{l}\text { FAALIYYETE } \\
\text { GEÇME YILI }\end{array}$ & 2015 & \\
\hline KAPASİTESİ & 76 & \\
\hline MEVCUT & Kadın & 29 \\
\hline KAPASİTE & Erkek & 41 \\
\hline & TOPLAM & 72 \\
\hline DOLULUK ORANI & $\% 94$ & \\
\hline
\end{tabular}

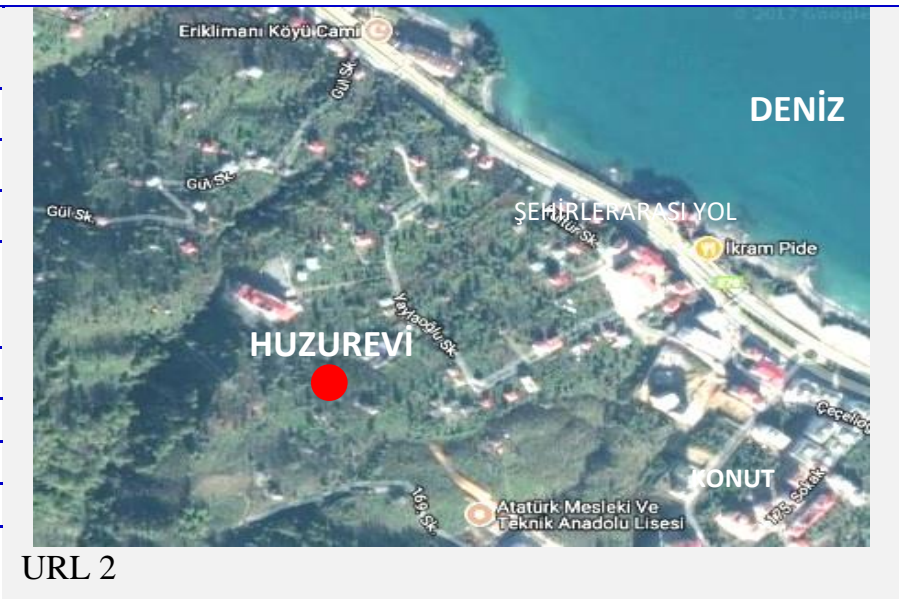

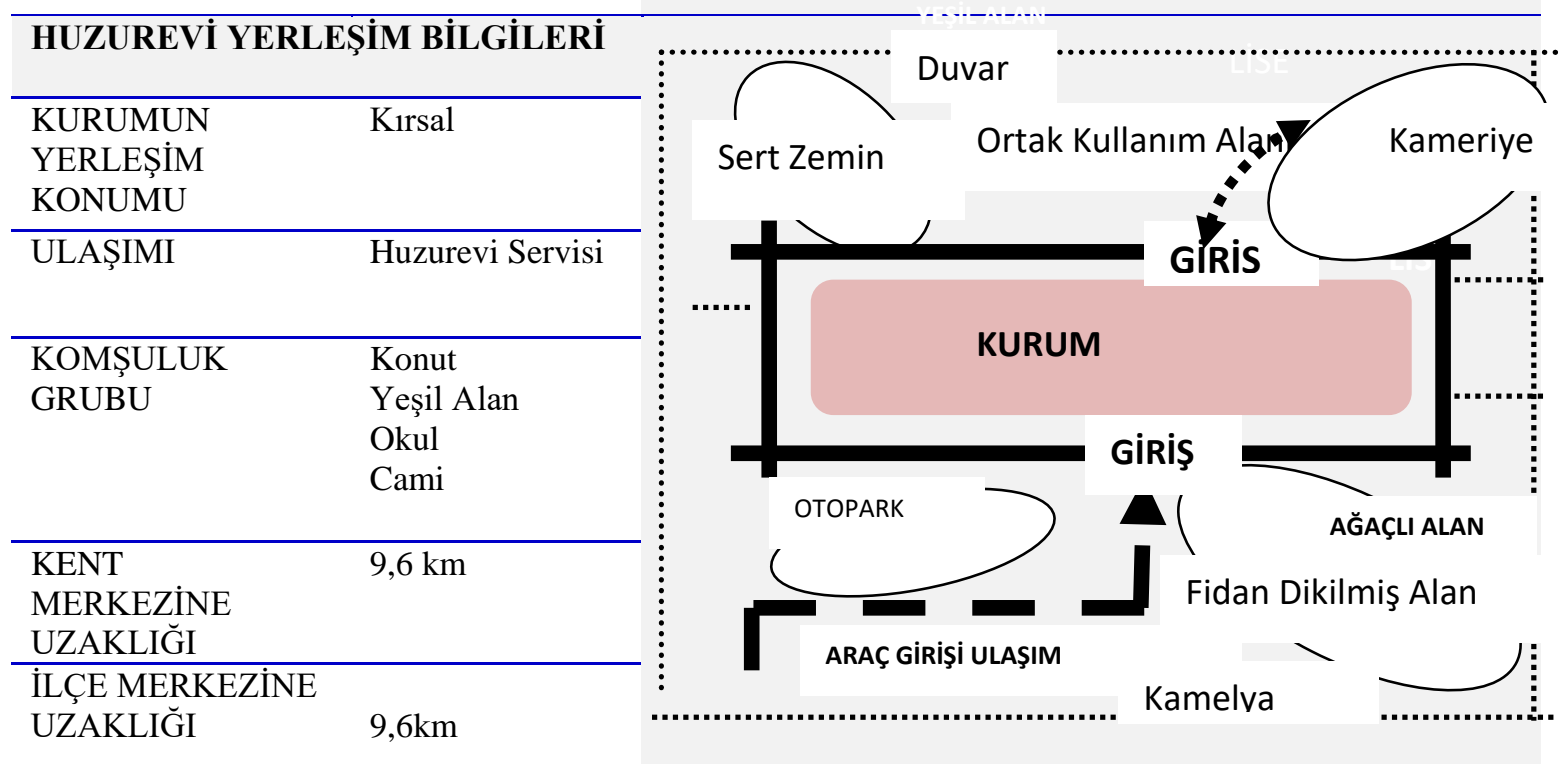

\begin{tabular}{|c|c|}
\hline \multicolumn{2}{|c|}{ AÇIK MEKÂN BİLGÍLERİ } \\
\hline $\begin{array}{l}\text { TOPLAM BAHÇE } \\
\text { METREKARESİ }\end{array}$ & $\begin{array}{l}9000 \mathrm{~m}^{2} \text { toplam alan } \\
2000 \mathrm{~m}^{2} \text { kapalı alan }\end{array}$ \\
\hline $\begin{array}{l}\text { SİRKÜLASYON } \\
\text { ELEMANLARI }\end{array}$ & Araç yolu, sert zeminler, gezinti yolu, merdiven ve rampa \\
\hline $\begin{array}{l}\text { ORTAK } \\
\text { KULLANIM } \\
\text { ALANLARI ve } \\
\text { DONATILAR }\end{array}$ & Kameriye, bank, sert zeminler \\
\hline $\begin{array}{l}\text { DONATI VE } \\
\text { YAPISAL PEYZAJ } \\
\text { ELEMANLARI }\end{array}$ & $\begin{array}{l}\text { Kameriye, oturma birimleri, oturma grubu, aydınlatma, Çöp kovaları, zemin } \\
\text { kaplaması, } \\
\text { Taşit yolu, duvar }\end{array}$ \\
\hline $\begin{array}{l}\text { BİTKİSEL PEYZAJ } \\
\text { ELEMANLARI }\end{array}$ & $\begin{array}{l}\text { Picea orientalis L., Cedrus libani A. Rich., Tilia platyphyllos Scop., Aesculus } \\
\text { hippocastanum L., Corylus avellana C. Koch. ,Rosa sp., Picea pungens 'Glauca', } \\
\text { Prunus ceracifera 'Atropurpurea' Rehd., Citrus limon L., Citrus sinensis L., } \\
\text { Juniperus L., Nerium oleander L., Lonicera hamamelis }\end{array}$ \\
\hline
\end{tabular}


Tablo 6. Ordu Ahmet Cemal Mağden Huzurevi Özellikleri (Eren, 2018)

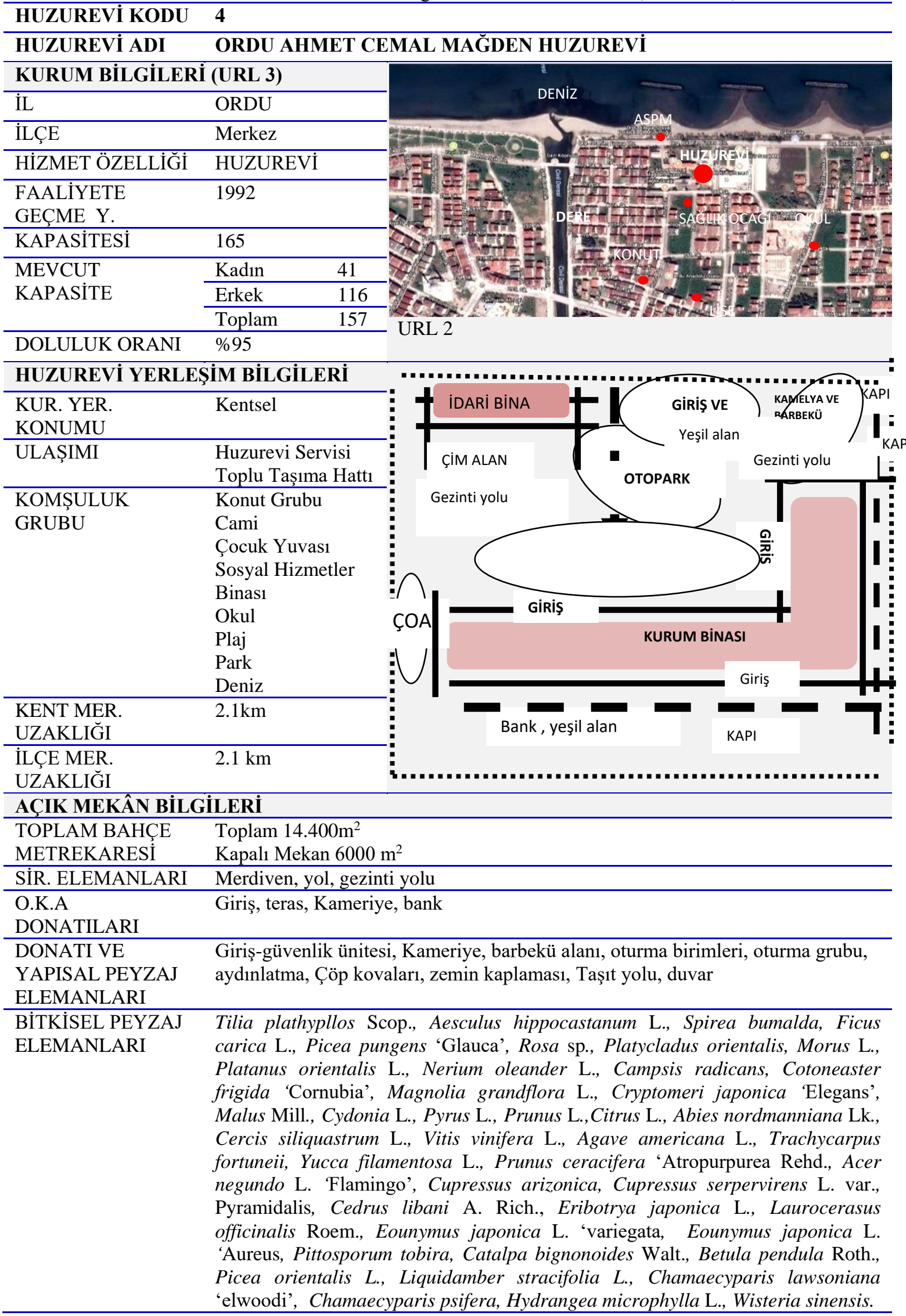


Tablo 7. Rize Fındıklı Huzurevi Özellikleri (Eren, 2018)

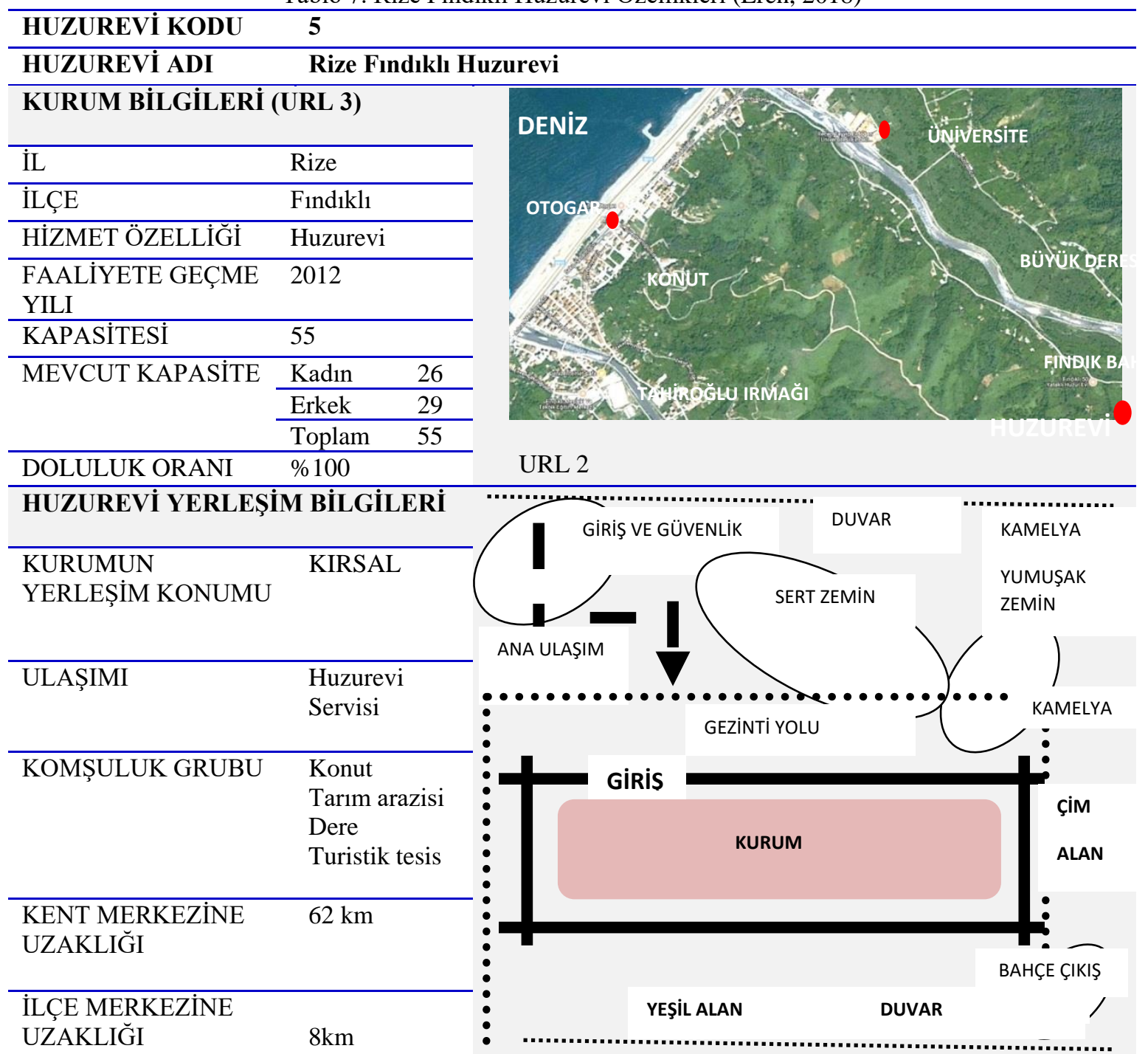

\section{AÇIK MEKÂN BÍLGÍLERI}

TOPLAM BAHÇE $\quad$ Toplam $6000 \mathrm{~m}^{2}$

METREKARESİ Açı alan $2000 \mathrm{~m}^{2}$

\begin{tabular}{ll}
\hline $\begin{array}{l}\text { SIRKÜLASYON } \\
\text { ELEMANLARI }\end{array}$ & Araç yolu, sert zeminler, gezinti yolu, merdiven ve rampa \\
\hline $\begin{array}{l}\text { ORTAK KULLANIM } \\
\text { ALANLARI }\end{array}$ & Kameriye, bank, sert zeminler \\
\hline $\begin{array}{l}\text { DONATI VE PEYZAJ } \\
\text { ELEMANLARI }\end{array}$ & $\begin{array}{l}\text { Giriş, güvenlik ünitesi, Kameriye, oturma birimleri, oturma grubu, aydınlatma, } \\
\text { Çöp kovaları, sert zemin-yumuşak zemin, Taşıt yolu, kümes, duvar }\end{array}$ \\
\hline BİTKİSEL PEYZAJ & $\begin{array}{l}\text { Tilia platyphyllos Scop., Rosa } \text { sp., Abies nordmanniana Lk., Picea abies L., } \\
\text { ELEMANLARI }\end{array}$ \\
$\begin{array}{l}\text { Picea orientalis, Platycladus orientalis L., Thujo occidentalis } \text { L., Hibiscus } \\
\text { syriacus L., Magnolia grandiflora } \text { L., Rhododendron azelea, Liquidambar } \\
\text { straciflua } \text { L. }\end{array}$ \\
\hline
\end{tabular}


Tablo 8. Trabzon Çamlık Huzurevinin Özellikleri (Eren, 2018)

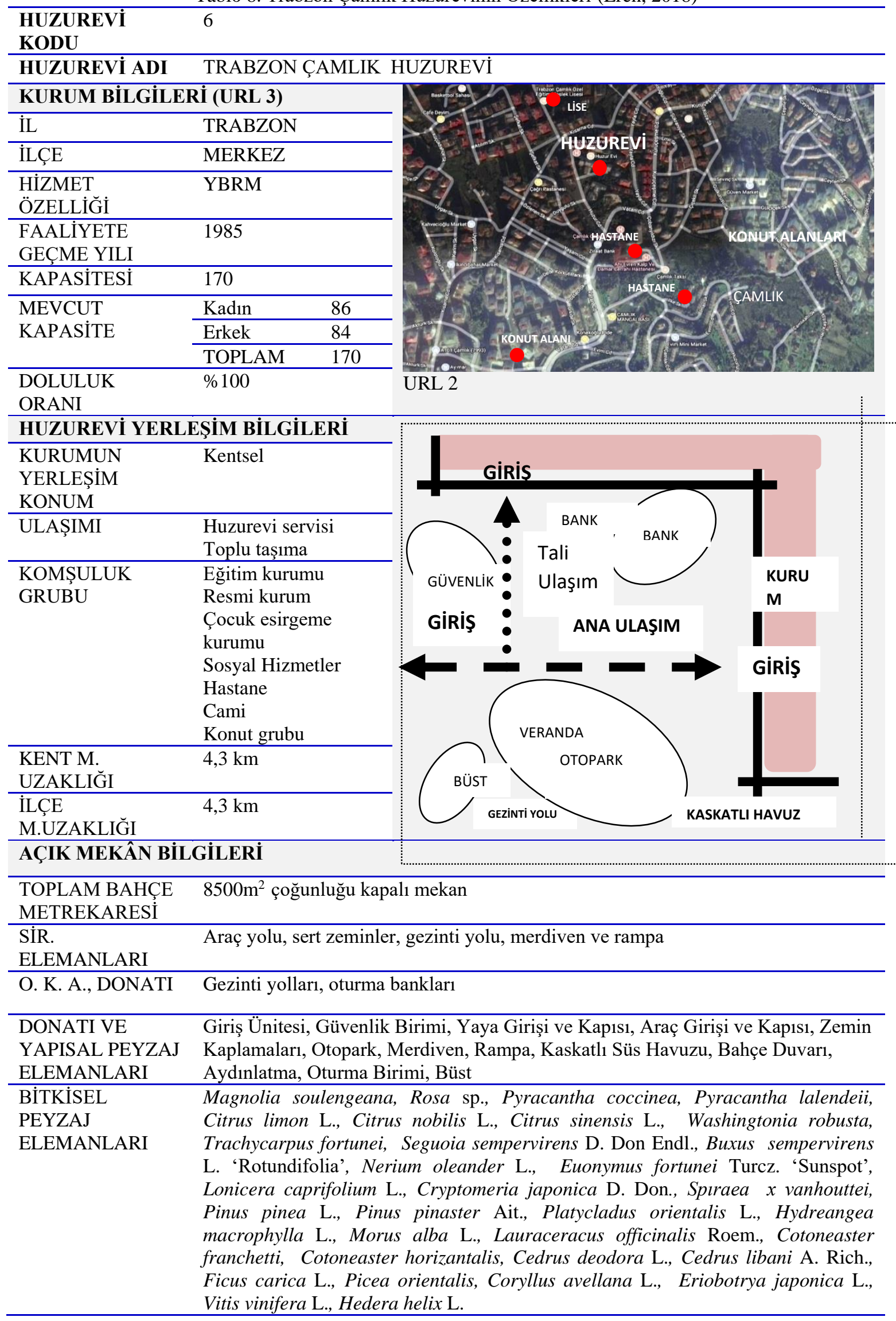


Tablo 9. Trabzon Köşk Huzurevinin Özellikleri (Eren, 2018)

\begin{tabular}{|c|c|c|}
\hline HUZUREVİ KODU & \multicolumn{2}{|l|}{7} \\
\hline HUZUREVİ ADI & \multicolumn{2}{|c|}{ Trabzon Köşk Huzu } \\
\hline \multicolumn{3}{|c|}{ KURUM BÍLGILERİ (URL 3) } \\
\hline$\dot{\mathrm{IL}} \mathrm{L}$ & \multicolumn{2}{|l|}{ Trabzon } \\
\hline İLÇE & \multicolumn{2}{|l|}{ Merkez } \\
\hline HİZMET ÖZELLİĞİ & \multicolumn{2}{|c|}{ HUZUREVİ } \\
\hline $\begin{array}{l}\text { FAALIYYETE GEÇME } \\
\text { YILI }\end{array}$ & \multicolumn{2}{|l|}{2012} \\
\hline KAPASITESİ & \multicolumn{2}{|l|}{73} \\
\hline \multirow[t]{3}{*}{ MEVCUT KAPASİTE } & Kadin & 20 \\
\hline & Erkek & 53 \\
\hline & Toplam & 73 \\
\hline
\end{tabular}

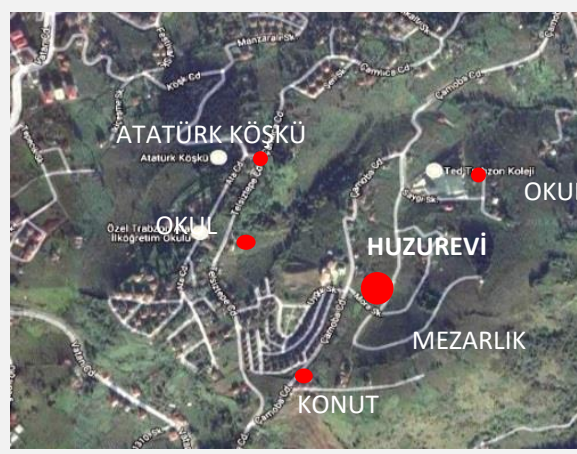

URL 2

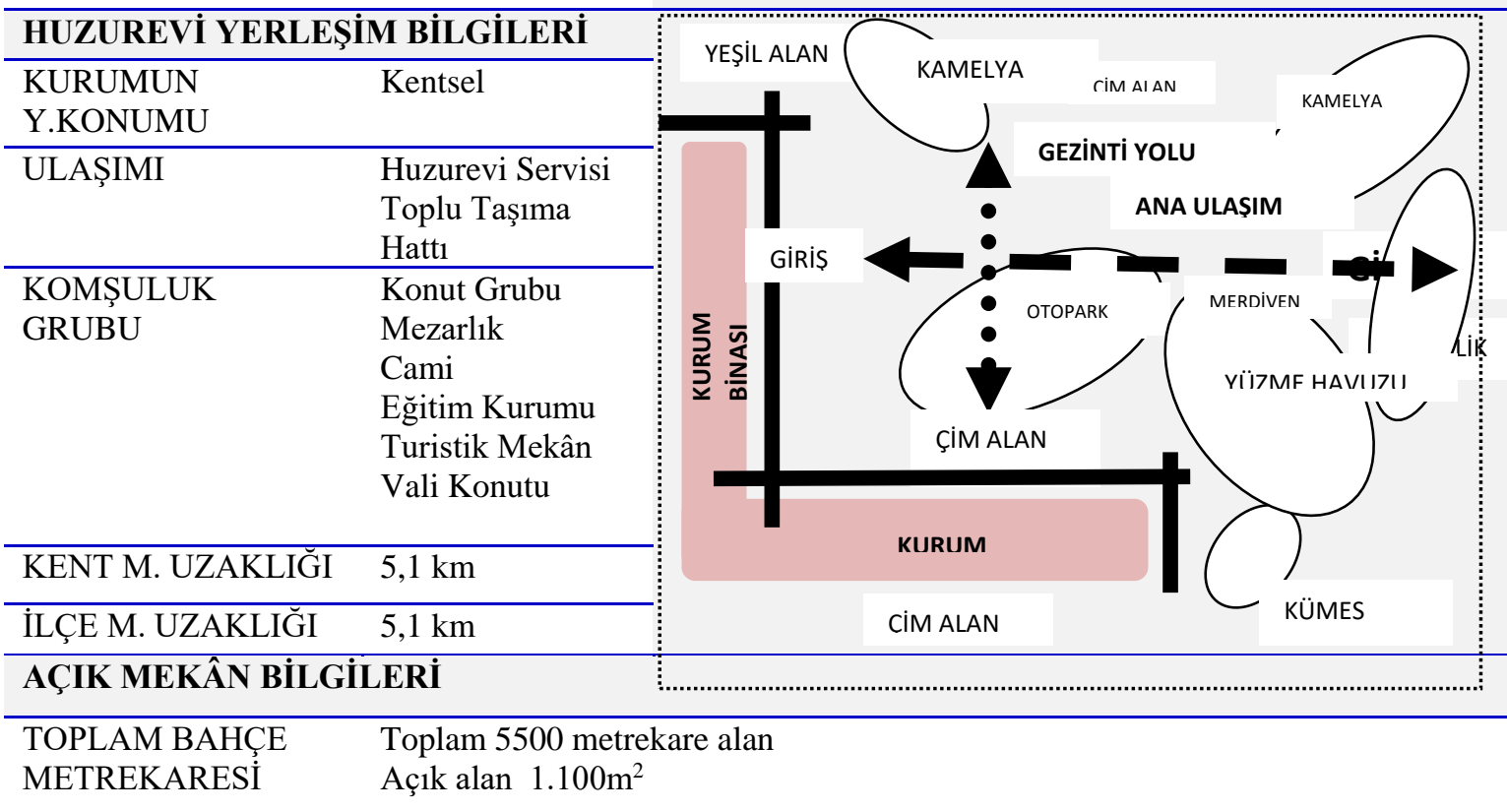

S. ELEMANLARI Araç yolu, sert zeminler, gezinti yolu, merdiven ve rampa

\begin{tabular}{|c|c|}
\hline K.A. DONATILARI & Kameriye, yüzme havuzu, gezinti yolları, oturma bankları \\
\hline $\begin{array}{l}\text { DONATI VE } \\
\text { YAPISAL PEYZAJ } \\
\text { ELEMANLARI }\end{array}$ & $\begin{array}{l}\text { Giriş Ünitesi, Güvenlik Birimi, Yaya Girişi ve Kapısı, Araç Girişi ve Kapısı, } \\
\text { Zemin Kaplamaları, Otopark, Merdiven, Rampa, Parapet, Yüzme Havuzu, } \\
\text { Kameriye, Bahçe Duvarı, Aydınlatma, Oturma Birimi, Oturma Grubu, Plastik } \\
\text { Obje, Kümes }\end{array}$ \\
\hline $\begin{array}{l}\text { BİTKİSEL PEYZAJ } \\
\text { ELEMANLARI }\end{array}$ & $\begin{array}{l}\text { Washingtonia robusta, Trachycarpus fortuneii, Cupressus macrocarpa } \\
\text { 'Goldcrest', Laurus nobilis L., Picea pungens 'Glauca', Picea pungens, Picea } \\
\text { orientalis, Pinus pinea L., Pinus pinaster Ait., Citrus limon L., Citrus nobilis } \\
\text { L., Citrus sinensis L., Thujo occidentalis L. 'Smarragd', Cercis siliguastrum L., } \\
\text { Araucaria heterophylla, Rosa } \text { sp., Vitis vinifera L., Hedera helix L., }\end{array}$ \\
\hline
\end{tabular}

\subsection{Huzurevlerine İlişkin Genel Değerlendirme Sonuçları}

Huzurevinin konumu, biçimlenişi, komşuluk grubu özellikleri, şehir merkezine yakınlığı, barındırdığı mekânlar ve bunların nitelikleri gibi ölçülebilir özellikleri fiziksel boyutunu oluşturmaktadır. Bu kapsamda, çalışmanın yürütüldüğü huzurevlerine ilişkin özellikler bir önceki bölümde belirlenerek tablolar halinde sunulmuştur.

Toplam kapasitesi en fazla olan huzurevi 170 kişi ile Trabzon Çamlık Huzurevi, en az ise 32 kişi ile Artvin Naime Ismail Yilmaz Huzurevidir (Şekil, 2). 


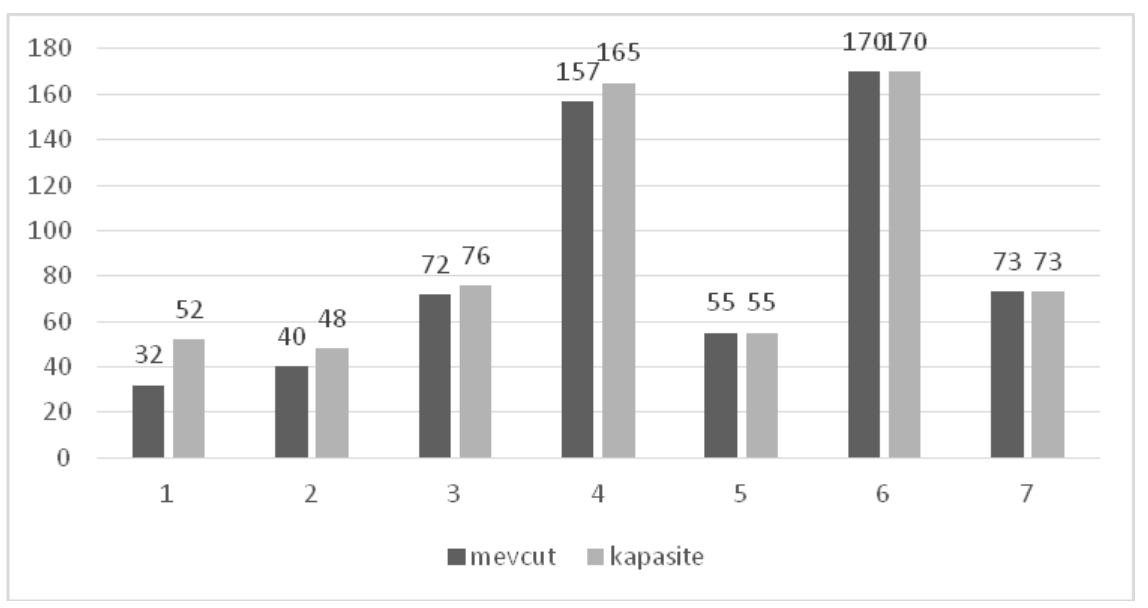

Şekil 2. Çalışma kapsamında ele alınan huzurevlerinin toplam ve mevcut kapasiteleri.

Kurum yerleşkelerinin konumları incelendiğinde ise; Ordu, Trabzon, Giresun illerindeki Huzurevleri kentsel alanlarda, Rize ve Artvin illerindekiler Merkez İlçe dışındaki ilçelerde ve kırsal kesimde bulunmaktadır. Kentsel alanda bulunan huzurevi sakinleri kentsel mekanlara daha kolay erişebilmektedir. Şehir merkezine ulaşım tüm huzurevlerinden servisler ile sağlanmakta, Trabzon ve Ordu'daki huzurevlerinde toplu taşıma araçları vasıtasıyla da sağlanmaktadır.

Komşuluk gruplarına bakıldığında kurum yerleşkelerinin konumları itibari ile Artvin Murgul ve Naime-Ismail Yılmaz Huzurevleri ile Rize Fındıklı Huzurevleri'nin ilçe ve kent merkezlerinden ayrılmış bölgelerde konumlandıkları belirlenmiş̧ir. Trabzon, Ordu ve Giresun Huzurevleri ise komşuluk grubu açısından konut grupları ve kentsel diğer işlev alanları ile bir arada konumlanmıştır. Trabzon Çamlık Huzurevi ve Ordu Ahmet Cemal Maden Huzurevleri çocuk yuvası, yetiştirme yurdu ve diğer sosyal hizmet birimleri ile bir arada bulunmaktadır (Tablo 10).

Tablo 10. Huzurevlerinin komşuluk grubunda bulunan işlevler.

\begin{tabular}{lccccccc}
\hline Komşuluk grubu & $\mathbf{7}$ & $\mathbf{2}$ & $\mathbf{3}$ & $\mathbf{4}$ & $\mathbf{5}$ & $\mathbf{6}$ & $\mathbf{7}$ \\
\hline Cami & $\mathbf{1}$ & - & - & $*$ & - & $*$ & $*$ \\
Konut grubu & $*$ & $*$ & $*$ & $*$ & $*$ & $*$ & $*$ \\
ASPK' ya bağlı birimler & - & - & - & $*$ & - & - & $*$ \\
Kamu kurum ve kuruluşu & - & - & - & $*$ & - & - & $*$ \\
Sağllk kuruluşu & - & $*$ & - & - & - & - & $*$ \\
Alışveriş-yeme-içme alanı & - & - & - & $*$ & - & - & $*$ \\
Eğitim kurumu & - & - & $*$ & - & - & - & $*$ \\
Açık yeşil alan & $*$ & $*$ & $*$ & $*$ & $*$ & $*$ & - \\
Mera & $*$ & $*$ & - & - & - & - & - \\
Mezarlık & - & - & - & $*$ & - & $*$ & - \\
Idari binalar & $*$ & $*$ & - & $*$ & - & - & $*$ \\
Turistik tesis & $*$ & - & - & - & - & - & - \\
Otel & $*$ & - & - & - & - & - & - \\
Plaj, deniz & - & - & - & $*$ & - & - & - \\
Dere & - & - & - & - & $*$ & - & - \\
Tarım arazisi & - & $*$ & $*$ & - & $*$ & $*$ & - \\
Inşaat sahası & - & $*$ & - & - & - & - & - \\
\hline
\end{tabular}

Huzurevlerinin sirkülason elemanları incelendiğinde; araştırmaya dahil edilen tüm huzurevlerinde yol ve rampa bulunduğu ancak, gezinti yolu ve merdivenin hepsinde bulunmadığı tespit edilmiştir. Tablo 11'de görüldüğü üzere Naime Ismail Yavuz ve Murgul Huzurevlerinin bahçelerinde gezinti yolu bulunmadığı tespit edilmiştir. Merdiven ise sadece Naime Ismail Yavuz Huzurevinde yoktur, diğer 6 huzurevi bahçesinde farklı şekillerde merdiven vardir. 
Tablo 11. Huzurevi bahçelerindeki sirkülasyon elemanları

\begin{tabular}{lccccccc}
\hline Sirkülasyon elemanı & \multicolumn{7}{c}{ Huzurevlerinin kodlar } \\
& $\mathbf{1}$ & $\mathbf{2}$ & $\mathbf{3}$ & $\mathbf{4}$ & $\mathbf{5}$ & $\mathbf{6}$ & $\mathbf{7}$ \\
\hline Yol & $*$ & $*$ & $*$ & $*$ & $*$ & $*$ & $*$ \\
Gezinti yolu & - & - & $*$ & $*$ & $*$ & $*$ & $*$ \\
Merdiven & - & $*$ & $*$ & $*$ & $*$ & $*$ & $*$ \\
Rampa & $*$ & $*$ & $*$ & $*$ & $*$ & $*$ & $*$ \\
\hline
\end{tabular}

Açık ve yeşil alan türlerinden hangilerinin hangi huzurevlerinde bulunup bulunmadığına Tablo 12 'de yer verilmiştir. Yedi huzurevinin hepsinde bulunan açık ve yeşil alanlar; otoparklar, yumuşak zeminli açık alanlar, sert zeminli açık alanlar ve oturma alanlarıdır. İç avlu, yalnızca sokak tipi yerleşim alanına sahip olduğu için Naime Ismail Yavuz Huzurevi bahçesinde vardır şeklinde değerlendirme yapılmıştır. Ancak tam anlamıyla bir iç avlu özelliğinde değildir. Diğer huzurevlerinde ise bulunmamaktadır. Arka bahçe Naime Ismail Yavuz ve Murgul Huzurevleri hariç diğerlerinde bulunmaktadır. Ancak her birindeki arka bahçeler tasarlanmış değildir. Daha çok boş bırakılmış alanlardır. Yürüyüş ve gezinti yolları sirkülasyon elemanı da olduğu için diğer başlık altında değerlendirilmiştir. Dinlenme alanı olarak nitelendirilebilecek açık ve yeşil alanlar; Ordu, Rize ve Trabzon'daki Huzurevlerinde vardır. Bahçede özellikle tasarlanmış bir yeme-içme alanı sadece Ahmet Cemal Mağden Huzurevinde mevcuttur. Bu alan bir barbekü alanı şeklindedir. Çocuk oyun alanı ise, Ahmet Cemal Mağden Huzurevi bahçesinde vardır. Hiç bir huzurevi bahçesinde toplu ve sosyal etkinlikler için tasarlanmış toplantı alanı yoktur. Spor alanı da sadece Ahmet Cemal Mağden Huzurevi bahçesinde vardır. Açık yüzme havuzu Trabzon Köşk Huzurevi bahçesinde bulunurken, diğerlerinde bulunmamaktadır. Veranda ve seyir alanları ise, Giresun, Ordu, Rize ve Trabzon Köşk Huzurevlerinde mevcuttur. Hayvan barınağı Rize ve Köşk Huzurevlerinin bahçelerinde bulunmaktadır. Bitki ekip dikmek için alan, Naime Ismail Yavuz Huzurevi bahçesinde mevcuttur, diğer huzurevlerinin hiçbirinde bulunmamaktadır.

Tablo 12. Huzurevi bahçelerindeki açık ve yeşil alanlar

\begin{tabular}{|c|c|c|c|c|c|c|c|}
\hline \multirow[t]{2}{*}{ Bahçedeki mekânlar } & \multicolumn{5}{|c|}{ Huzurevlerinin kodları } & \multirow[b]{2}{*}{6} & \multirow[b]{2}{*}{7} \\
\hline & 1 & 2 & 3 & 4 & 5 & & \\
\hline Giriş ve güvenlik ünitesi & $*$ & $*$ & - & $*$ & $*$ & $*$ & $*$ \\
\hline Otopark & $*$ & $*$ & $*$ & * & * & $*$ & $*$ \\
\hline Yeşil alan & $*$ & $*$ & $*$ & * & * & $*$ & $*$ \\
\hline Sert zemin & $*$ & $*$ & $*$ & * & $*$ & $*$ & $*$ \\
\hline Iç avlu & $*$ & - & - & - & - & - & - \\
\hline Arka bahçe & - & - & $*$ & * & $*$ & $*$ & $*$ \\
\hline Yürüyüş alanları/gezinti yolu & - & - & $*$ & $*$ & $*$ & $*$ & $*$ \\
\hline Dinlenme alanları & - & - & - & * & * & $*$ & $*$ \\
\hline Yeme- içme alanı & - & - & - & $*$ & - & - & - \\
\hline Barbekü alanı & - & - & - & $*$ & - & - & - \\
\hline Çocuk oyun alanı & - & - & - & $*$ & - & - & - \\
\hline Toplant1 alanları & - & - & - & - & - & - & - \\
\hline Oturma alanı & $*$ & $*$ & $*$ & $*$ & $*$ & $*$ & $*$ \\
\hline Spor alanı & - & - & - & * & - & - & - \\
\hline Yüzme havuzu & - & - & - & - & - & - & $*$ \\
\hline Veranda/teras/seyir alan 1 & - & - & $*$ & $*$ & $*$ & - & $*$ \\
\hline Hayvan barınağ & - & - & - & - & * & - & $*$ \\
\hline Bitki yetiştirme alanı/sera & $*$ & - & - & - & - & - & - \\
\hline Açık alan & - & - & - & - & - & - & - \\
\hline
\end{tabular}

Huzurevi bahçelerinde bulunan donatı ve yapısal peyzaj elemanları Kameriye, zemin kaplamaları, aydınlatma elemanları, duvar elemanları, bank ve çöp kovaları tüm huzurevi bahçelerinde bulunduğu tespit edilmiştir (Tablo13). 
Tablo 13. Huzurevi bahçelerindeki donatı ve yapısal peyzaj elemanları

\begin{tabular}{lccccccc}
\hline Donatı ve Yapısal peyzaj elemanları & \multicolumn{7}{c}{ Huzurevlerinin kodları } \\
& $\mathbf{1}$ & $\mathbf{2}$ & $\mathbf{3}$ & $\mathbf{4}$ & $\mathbf{5}$ & $\mathbf{6}$ & $\mathbf{7}$ \\
\hline Kameriye & $*$ & $*$ & $*$ & $*$ & $*$ & $*$ & $*$ \\
Bank & $*$ & $*$ & $*$ & $*$ & $*$ & $*$ & $*$ \\
Oturma grubu & $*$ & $*$ & $*$ & $*$ & $*$ & - & $*$ \\
Sert zeminler & $*$ & $*$ & $*$ & $*$ & $*$ & $*$ & $*$ \\
Aydınlatma & $*$ & $*$ & $*$ & $*$ & $*$ & $*$ & $*$ \\
Duvar & $*$ & $*$ & $*$ & $*$ & $*$ & $*$ & $*$ \\
Çöp kutusu & $*$ & $*$ & $*$ & $*$ & $*$ & $*$ & $*$ \\
Yaya giriş kapısı & $*$ & $*$ & - & $*$ & $*$ & $*$ & $*$ \\
Araç giriş kapısı & $*$ & $*$ & - & $*$ & $*$ & $*$ & $*$ \\
Güvenlik birimi & $*$ & $*$ & - & $*$ & $*$ & $*$ & $*$ \\
Plastik obje & $*$ & $*$ & - & $*$ & - & $*$ & $*$ \\
Yönlendirme/bilgilendirme panosu & - & - & - & $*$ & - \\
\hline
\end{tabular}

Araştırmaya dahil edilen tüm huzurevi bahçelerinde yapılan yerinde tespit çalışmalarında saptanan bitki taksonları bunların hangi huzurevlerinde bulunduğu Tablo 14' de sunulmuştur. Tabloya göre 54 farklı cins ve 79 tür ve bu türlerin bazılarına ait alttürler tespit edilmiştir. En az bitki Murgul ve Naime Ismail Yavuz Huzurevlerinin bahçelerinde tespit edilmiştir. En çok bitki türü ve sayısı ise Ahmet Cemal Mağden Huzurevi bahçesinde tespit edilmiştir.

Tablo 14. Huzurevi bahçelerinde saptanan bitki taksonları

\begin{tabular}{|c|c|c|c|c|c|c|c|}
\hline \multirow[t]{2}{*}{ Bitki taksonları } & \multicolumn{7}{|c|}{ Huzurevlerinin kodları } \\
\hline & 1 & 2 & 3 & 4 & 5 & 6 & 7 \\
\hline Abies nordmanniana Lk. & - & - & - & $*$ & $*$ & - & - \\
\hline Acer platonoides $\mathrm{L}$. & - & * & - & - & - & - & - \\
\hline Acer negundo L. 'Flamingo' & - & - & - & * & - & - & - \\
\hline Aesculus hippocastanum L. & - & - & $*$ & * & - & - & - \\
\hline Agave americana $\mathrm{L}$. & - & - & - & $*$ & - & - & - \\
\hline Araucaria heterophylla & - & - & - & - & - & - & $*$ \\
\hline Betula pendula Roth. & - & - & - & * & - & - & - \\
\hline Betula litwinowii & - & $*$ & - & - & - & - & - \\
\hline Buxus sempervirens L. 'Rotundifolia' & - & - & - & - & - & $*$ & - \\
\hline Campsis radicans $\mathrm{L}$. & - & - & - & $*$ & - & - & - \\
\hline Catalpa bignonoides Walt. & - & - & - & * & - & - & - \\
\hline Cedrus deodora $\mathrm{L}$. & - & - & - & - & - & $*$ & - \\
\hline Cedrus libani A. Rich. & - & - & $*$ & * & - & $*$ & - \\
\hline Cercis siliquastrum $\mathrm{L}$. & - & - & - & * & - & - & $*$ \\
\hline Chamaecyparis lawsoniana 'Elwoodi' & - & - & - & * & - & - & - \\
\hline Chamaecyparis psifera & - & - & - & * & - & - & - \\
\hline Citrus limon $\mathrm{L}$. & - & - & $*$ & * & - & $*$ & $*$ \\
\hline
\end{tabular}


Tablo 14. Huzurevi bahçelerinde saptanan bitki taksonları (devamı)

\begin{tabular}{|c|c|c|c|c|c|c|c|}
\hline \multirow{2}{*}{ Bitki taksonları } & \multicolumn{7}{|c|}{ Huzurevlerinin kodları } \\
\hline & 1 & 2 & 3 & 4 & 5 & 6 & 7 \\
\hline Citrus nobilis L. & - & - & - & $*$ & - & $*$ & $*$ \\
\hline Citrus sinensis L. & - & - & $*$ & $*$ & - & $*$ & $*$ \\
\hline Cotoneaster franchetti & - & - & - & - & - & $*$ & - \\
\hline Cotoneaster horizantalis & - & - & - & - & - & $*$ & - \\
\hline Cotoneaster frigida 'Cornubia' & - & - & - & $*$ & - & - & - \\
\hline Corylus avellana $\mathrm{L}$. & - & - & $*$ & - & - & $*$ & - \\
\hline Cryptomeria japonica D. Don. & - & - & - & - & - & $*$ & - \\
\hline Cryptomeri japonica D. Don. 'Elegans' & - & - & - & $*$ & - & - & - \\
\hline Cupressus arizonica & - & - & - & $*$ & - & - & - \\
\hline Cupressus serpervirens L. var. 'Pyramidalis' & - & - & - & $*$ & - & - & - \\
\hline Cupressus macrocarpa 'Goldcrest' & - & - & - & - & - & - & $*$ \\
\hline Cydonia L. & - & - & - & $*$ & - & - & - \\
\hline Eriobotrya japonica $\mathrm{L}$. & - & - & - & $*$ & - & $*$ & - \\
\hline Euonymus fortunei 'Sunspot' Turcz. & - & - & - & - & - & $*$ & - \\
\hline Euonymus japonica variegata & - & - & - & $*$ & - & - & - \\
\hline Eounymus japonica 'Aureus' & - & - & - & $*$ & - & - & - \\
\hline Ficus carica L. & - & - & - & $*$ & - & $*$ & - \\
\hline Hedera helix $\mathrm{L}$. & - & - & - & - & - & $*$ & $*$ \\
\hline Hibiscus syriacus L. & - & - & - & - & $*$ & - & - \\
\hline Hydrangea microphylla $\mathrm{L}$. & - & - & - & $*$ & - & $*$ & - \\
\hline Juglans regia L. & $*$ & - & - & - & - & - & - \\
\hline Juniperus pfitzeriana & - & $*$ & - & - & - & - & - \\
\hline Juniperus L. & - & - & $*$ & - & - & - & - \\
\hline Lauraceracus officinalis & - & - & - & $*$ & - & $*$ & - \\
\hline Laurus nobilis L. & - & - & - & - & - & - & $*$ \\
\hline Lonicera caprifolium $\mathrm{L}$. & - & - & - & - & - & $*$ & - \\
\hline Lonicera hamamelis & - & - & $*$ & - & - & - & - \\
\hline Liquidamber stracifolia $\mathrm{L}$. & - & - & - & $*$ & $*$ & - & - \\
\hline Malus L. & - & - & - & $*$ & - & - & - \\
\hline Magnolia grandiflora L. & - & - & - & $*$ & $*$ & - & - \\
\hline Magnolia soulengeana & - & - & - & - & - & $*$ & - \\
\hline Morus alba $\mathrm{L}$. & - & - & - & - & - & $*$ & - \\
\hline Nerium oleander L. & - & - & $*$ & $*$ & - & $*$ & - \\
\hline Picea abies L. & - & - & - & - & $*$ & - & - \\
\hline Picea pungens 'Glauca' & - & $*$ & $*$ & $*$ & - & - & $*$ \\
\hline Picea pungens & - & * & - & - & - & - & $*$ \\
\hline Picea orientalis & - & - & $*$ & $*$ & $*$ & $*$ & $*$ \\
\hline Pinus pinea $\mathrm{L}$. & - & - & - & - & - & $*$ & $*$ \\
\hline Pinus pinaster Ait. & - & - & - & - & - & $*$ & $*$ \\
\hline Pinus sp. & $*$ & $*$ & - & - & - & - & - \\
\hline Pittosporum tobira & - & - & - & $*$ & - & - & - \\
\hline Platanus orientalis L. & - & - & - & $*$ & - & - & - \\
\hline Platycladus orientalis L. & - & - & - & $*$ & $*$ & $*$ & - \\
\hline Pyracantha coccinea & - & - & - & - & - & $*$ & - \\
\hline Pyracantha lalendeii & - & - & - & - & - & $*$ & - \\
\hline
\end{tabular}


Tablo 14. Huzurevi bahçelerinde saptanan bitki taksonları (devamı)

\begin{tabular}{|c|c|c|c|c|c|c|c|}
\hline \multirow[t]{2}{*}{ Bitki taksonları } & \multicolumn{7}{|c|}{ Huzurevlerinin kodları } \\
\hline & $\mathbf{1}$ & 2 & 3 & 4 & 5 & 6 & 7 \\
\hline Pyrus L. & - & - & - & $*$ & - & - & - \\
\hline Prunus sp. & - & - & - & $*$ & - & - & - \\
\hline Prunus ceracifera 'Atropurpurea' Rehd. & - & $*$ & $*$ & $*$ & - & - & - \\
\hline Rhododendron azelea & - & - & - & - & $*$ & - & - \\
\hline Rosa subsp. & - & - & * & * & $*$ & $*$ & * \\
\hline Robinia pseudoacacia 'Umbraculifera' & - & $*$ & - & - & - & - & - \\
\hline Seguoia sempervirens D. Don. & - & - & - & - & - & $*$ & - \\
\hline Spirea bumalda & - & - & - & * & - & - & - \\
\hline Spiraea $x$ vanhouttei & - & - & - & - & - & * & - \\
\hline Tilia platyphyllos Scop. & - & - & $*$ & $*$ & * & - & - \\
\hline Thujo occidentalis L. & - & $*$ & - & - & $*$ & - & - \\
\hline Thujo occidentalis 'Smarragd' & - & - & - & - & - & - & * \\
\hline Trachycarpus fortuneii & - & - & - & $*$ & - & * & $*$ \\
\hline Vitis vinifera $\mathrm{L}$. & - & - & - & $*$ & - & * & * \\
\hline Wisteria sinensis & - & - & - & $*$ & - & - & - \\
\hline Washingtonia robusta & - & - & - & - & - & * & * \\
\hline Yucca filamentosa $\mathrm{L}$. & - & - & - & $*$ & - & - & - \\
\hline
\end{tabular}

\subsection{Aşama 2'ye Iliş̧kin Bulgular}

Anketlere katılan kişilerin demografik bilgilerini belirlemek amacıyla sorulan anket sorusunun verileri ise Tablo 15 'deki gibidir.

Tablo 15. Her bir huzurevinden ankete katılan yaşlıların demografik bilgileri

\begin{tabular}{|c|c|c|c|c|c|c|c|c|}
\hline \multirow{2}{*}{\multicolumn{2}{|c|}{ Demografik özellikler }} & \multirow[b]{2}{*}{1} & \multicolumn{6}{|c|}{ Huzurevlerinin kodları } \\
\hline & & & 2 & 3 & 4 & 5 & 6 & 7 \\
\hline Toplam kişi & & 7 kişi & 8 kişi & 15 kişi & 35 Kişi & 12 kişi & 12 kişi & 41 kişi \\
\hline \multirow{3}{*}{ Kalış süresi } & $1 \mathrm{y} 1 \mathrm{l}$ & 3kişi & 5 kişi & 7 kişi & 16 Kişi & 2 Kişi & 2 kişi & 12 kişi \\
\hline & 2 yıl & 4kişi & 3 kişi & 8 kişi & 11 Kişi & 4 Kişi & 3 kişi & 23 kişi \\
\hline & 2 yıl üzeri & - & - & - & 8 Kişi & 6 Kişi & 7 kişi & 6 kişi \\
\hline \multirow{2}{*}{ Kalış şekli } & Ücretli & 2 kişi & 3 kişi & 2 kişi & 7 Kişi & 4 Kişi & 5 kişi & 15 kişi \\
\hline & Ücretsiz & 5 kişi & 5 kişi & 13 kişi & 28 Kişi & 8 Kişi & 7 kişi & 26 kişi \\
\hline \multirow{2}{*}{$\begin{array}{l}\text { Ekonomik } \\
\text { durumu }\end{array}$} & Maaşı var & 2 kişi & 5 kişi & 2 kişi & 7 Kişi & 4Kişi & 5 kişi & 15 kişi \\
\hline & Maaşı yok & 5 kişi & 3 kişi & 13 kişi & 28 Kişi & 8 Kişi & 7 kişi & 26 kişi \\
\hline \multirow{2}{*}{ Sağlık durumu } & Özel bakım & - & - & - & - & - & - & - \\
\hline & Sağlıklı & 7 kişi & 8 kişi & 15 kişi & 35 Kişi & 12 Kişi & 12 kişi & 41 kişi \\
\hline \multirow{2}{*}{ Medeni durum } & Evli & 1 kişi & 1 kişi & 2 kişi & 5 Kişi & 3 Kişi & 2 kişi & 5 kişi \\
\hline & Bekar & 6 kişi & 7 kişi & 13 kişi & 30 Kişi & 9 Kişi & 10 kişi & 36 kişi \\
\hline \multirow{6}{*}{ Eğitim durumu } & Okur-yazar d. & 2 kişi & - & 3 kişi & 5 Kişi & 2 Kişi & 2 kişi & 4 kişi \\
\hline & Okur-yazar & 1 kişi & 1 kişi & 9 kişi & 7 Kişi & 7 Kişi & 3 kişi & 13 kişi \\
\hline & İlkokul & 2 kişi & 2 kişi & 1 kişi & 15 Kişi & 1 Kişi & 4 kişi & 11 kişi \\
\hline & Lise & 2 kişi & 3 kişi & - & 5 Kişi & 1 Kişi & 3 kişi & 10 kişi \\
\hline & Önlisans & - & 1 kişi & - & 1 Kişi & - & - & 1 kişi \\
\hline & Lisans & - & 1 kişi & 2 kişi & 2 Kişi & 1 Kişi & - & 2 kişi \\
\hline \multirow{2}{*}{ Cinsiyet } & Bayan & 2 kişi & 2 kişi & 3 kişi & 5 Kişi & 2 kişi & 1 kişi & 4 kişi \\
\hline & Bay & 5 kişi & 6 kişi & 12 kişi & 30 Kişi & 10 kişi & 11 kişi & 37 kişi \\
\hline
\end{tabular}


Tablo 15. Her bir huzurevinden ankete katılan yaşlıların demografik bilgileri (devamı)

\begin{tabular}{|c|c|c|c|c|c|c|c|c|}
\hline \multirow{2}{*}{\multicolumn{2}{|c|}{ Demografik özellikler }} & \multirow[b]{2}{*}{1} & \multicolumn{6}{|c|}{ Huzurevlerinin kodları } \\
\hline & & & 2 & 3 & 4 & 5 & 6 & 7 \\
\hline \multirow{15}{*}{ Memleket } & Ankara & - & - & - & - & - & - & 2 kişi \\
\hline & Artvin & 6 kişi & 8 kişi & - & - & - & - & - \\
\hline & Antalya & - & - & - & - & - & - & 1kişi \\
\hline & Ardahan & 1kişi & - & - & - & - & - & - \\
\hline & İstanbul & - & - & - & - & - & - & 2 kişi \\
\hline & Balıkesir & - & - & - & - & - & - & 1 kişi \\
\hline & Sivas & - & - & - & - & - & - & 1 kişi \\
\hline & Erzurum & - & - & - & - & - & - & 1 kişi \\
\hline & Rize & - & - & - & - & 12Kişi & - & 2 kişi \\
\hline & Trabzon & - & - & - & - & - & 12 kişi & 25 kişi \\
\hline & Ordu & - & - & - & 35 Kişi & - & - & - \\
\hline & Giresun & - & - & 15 kişi & - & - & - & 2 kişi \\
\hline & Çorum & - & - & - & - & - & - & 2 kişi \\
\hline & Bursa & - & - & - & - & - & - & 1 kişi \\
\hline & Aydın & - & - & - & - & - & - & 1 kişi \\
\hline \multirow{5}{*}{ Yaş } & $60-64$ & 2 kişi & 3 kişi & 3 kişi & 7 Kişi & 2 kişi & 1 kişi & 6 kişi \\
\hline & $65-69$ & 3 kişi & 1 kişi & 6 kişi & 14 Kişi & 5 kişi & 4 kişi & 14 kişi \\
\hline & $70-74$ & - & 2 kişi & 3 kişi & 5 Kişi & 3 kişi & 5 kişi & 12 kişi \\
\hline & $75-79$ & 1 kişi & 1 kişi & 1 kişi & 7Kişi & 1 kişi & 1 kişi & 5 kişi \\
\hline & 80 ve üstü & 1 kişi & 1 kişi & 1 kişi & 2 Kişi & 1 kişi & 1 kişi & 4kişi \\
\hline
\end{tabular}

\subsection{Aşama 3'e İlişkin Bulgular}

Huzurevine şehirden erişim, kurum içindeki erişim, kurum bahçesi ve konumu, huzurevinin yakın çevresindeki diğer işlev alanları, şehir merkezine olan uzaklığından, bahçenin tasarımından, içerdiği mekanlardan, bahçedeki yapısal peyzaj elemanlarından, bitkisel peyzaj elemanlarından, bahçe içindeki sirkülasyon elemanlarından, bahçenin koşullarından, diğer huzurevi sakinleri ile birlikte bahçeyi kullanmaktan, ortak mekanları kadın erkek bir arada kullanmaktan duydukları memnuniyeti ölçmek için 14 ifade likert tipi ölçek hazırlanan anket aracılığıyla katılımcılara uygulanmıștır. Huzurevi bahçelerindeki fiziksel koşulların kullanıcılar tarafından değerlendirilmesi ve kullanıcının bu konudaki memnuniyet düzeyi belirlenmeye çalışılırken düzey belirleyen değerlerden 1-2 değerleri olumlu, 3 değeri konu ile ilgili görüşü olmayan, fikir beyan etmek istemeyen ve 4-5 değerleri olumsuz değerlerdir. Yani ankette huzurevi bahçelerinin fiziksel koşullarından memnuniyet duyduğu sonucu 1 ve 2 değerleri, 4 ve 5 değerleri memnuniyetsizlik duyduğu sonucunu 3 değeri ise konu ile ilgili fikir beyan etmek istemediği sonucunu çıkarmaktadır.

İlk olarak bahçelerin fiziksel koşullarına ilişkin sorulara ait değerlendirmeler yapılmadan önce, ölçeğe faktör analizi yapılmış ve birbirleriyle ilişkili değişkenler bir araya getirilerek kavramsal olarak alt faktörler belirlenmiştir.

Analizde varimax rotasyonlu temel bileşenler analizi uygulanmış, sonucu 0,40 dan düşük faktör yükleri gizlenmiştir. Böylece 14 ifadeden faktör yükü 0,40 altında olan 4 ifade ölçekten atılmış, ölçek 10 ifadeye düşmüştür (Tablo, 16). 10 ifade 3 faktör grubu altında toplanmış, bu faktörlerin toplam varyansı $\% 58,873$ çıkmıştır. Bu değer istenen \%50 seviyesinin üzerindedir. Bu ölçeğin faktör analizine uygunluğunun tespiti için Kraiser Meyer Olkin (KMO) değeri ,700 ve Barlett küresellik testi x2: 1,577, df:91, p <000 olarak tespit edilmiştir. Ayrıca elde edilen faktör gruplarının güvenirliliğini ortaya koymak için Cronbach 'ın Alpha analizi yapılmıştır. Ölçeğin güvenirliliğine yönelik tamamının Cronbach Alpha değeri ,762 bulunmuştur. Bu değerde istenen \% 70 seviyesinin üzerindedir. Ayrıca kullanıcıların değerlendirmeleri öncelikli olarak çarpıklık (skewness) ve basıklık (kurtosis) değerleri verilerinin normal dağılım gösterip göstermediğine göre incelenmiş̧tir. Bu değerlerin $+1,5,-1,5$, değerleri arasında dağılım gösterdiği tespit edilmiş̧tir. 
Tablo 16. Huzurevlerinin mevcut fiziksel özelliklerine ilişkin faktör grupları ve analizleri

\begin{tabular}{|c|c|c|c|c|c|}
\hline $\begin{array}{l}\text { Faktör } \\
\text { Grupları }\end{array}$ & Ifadeler & $\begin{array}{l}\text { Faktör } \\
\text { Yükü }\end{array}$ & Varyans & Özdeğeri & $\begin{array}{c}\text { Güvenirlik } \\
(\alpha)\end{array}$ \\
\hline \multirow{4}{*}{ 1. Faktör } & Huzurevi bahçesinden memnuniyet & ,983 & \multirow{4}{*}{$\% 28,068$} & \multirow{4}{*}{3,930} & \multirow{4}{*}{,990 } \\
\hline & Huzurevi ve bahçesinin & 984, & & & \\
\hline & konumundan memnuniyet & ,904 & & & \\
\hline & $\begin{array}{l}\text { Huzurevinin yakın çevresindeki } \\
\text { işlev alanlarından memnuniyet }\end{array}$ & ,966 & & & \\
\hline \multirow{3}{*}{ 2. Faktör } & Şehir merkezine uzaklık & ,960 & \multirow{3}{*}{$\% 16,277$} & \multirow{3}{*}{2,279} & \multirow{3}{*}{,972 } \\
\hline & Şehirden kuruma erişilebilirlik & 967 & & & \\
\hline & Kurum bahçesindeki erişilebilirlik & ,945 & & & \\
\hline \multirow{5}{*}{ 3. Faktör } & $\begin{array}{l}\text { Bahçedeki yapısal peyzaj } \\
\text { elemanlarından memnuniyet }\end{array}$ &, 850 & \multirow{5}{*}{$\% 14,528$} & \multirow{5}{*}{2,034} & \multirow{5}{*}{,673 } \\
\hline & Bahçedeki bitkisel peyzaj & ,426 & & & \\
\hline & Bahcedeki sirkülasyon & & & & \\
\hline & elemanlarından memnuniyet & ,816 & & & \\
\hline & $\begin{array}{l}\text { Bahçenin içerdiği mekanlardan } \\
\text { memnuniyet }\end{array}$ &, 577 & & & \\
\hline
\end{tabular}

1. Faktör grubu altında yüklenen ifadelere bakıldığında, literatürde konumsal özelliklerle örtüşme sağladığından 'konumsal özellikler' olarak isimlendirilmiştir. Bu faktör tek başına toplam varyansın \% 28,068' ini oluşturmakta ve üç ifadeden oluşmaktadır. En yüksek güvenirlilik düzeyine sahiptir $(\alpha=0,990)$.

2. Faktör grubu altında yüklenen ifadelere bakıldığında, literatürde erişilebilirlik özellikleri ile örtüşme sağladığından 'erişilebilirlik' özellikleri olarak isimlendirilmiştir. Bu faktör grubu üç ifadeden oluşmaktadır. Toplam varyansın \%16,277'sini oluşturmaktadır. Güvenirlilik düzeyi 0,972 dir.

3. Faktör grubuna bakıldığında daha çok bahçenin 'peyzaj tasarımı' ile ilgili ifadeler yüklenmiştir. Toplam dört ifadeden oluşmaktadır. Bu sebeple 'tasarım özellikleri' olarak isimlendirilmiştir. Toplam varyansın \%14,528'ini oluşturmaktadır. En düşük güvenirlik düzeyine sahip faktör grubudur.

Araştırmanın bu bölümünde, elde edilen faktörlerle gerçekleştirilen analizler yer almaktadır. Her bir huzurevi için, kullanıcılar tarafından yapılan değerlendirme sonucunda faktörlerin aldıkları ortalama değerler hesaplamış ve bu ortalamaların huzurevlerine göre farklılaşıp farklılaşmadığı ANOVA testi ile hesaplanmıştır (Tablo 17).

\section{Sonuç ve Öneriler}

$\mathrm{Bu}$ çalışmada, huzurevi bahçelerindeki çevresel memnuniyet düzeylerinin belirlenmesi üzerine bir araştırma gerçekleştirilmiştir.

Çalışmanın en önemli yönlerinden biri, farklı disiplinlerin lisansüstü ve akademik çalışmalarda sıklıkla ele aldığı yaşlı, huzurevi, memnuniyet konularını, fiziksel özellikler bağlamında ele alması ve peyzaj mimarlığı açısından ilişkilendirmesi ve huzurevi bahçeleri için çevresel memnuniyet düzeyinin artması için sahip olması gereken özellikleri ortaya koymasıdır. 21. 02.2001'de 24325 sayılı resmi gazetede yayınlanan Aile ve Sosyal Politikalar Bakanlığı, Engelli ve Yaşlı Hizmetleri Genel Müdürlüğünün, Huzurevleri ile huzurevi yaşlı bakım ve rehabilitasyon merkezleri yönetmeliğinde (Huzurevleri İle Huzurevi Yaşlı Bakım Ve Rehabilitasyon Merkezleri Yönetmeliği 828 Sayılı Sosyal Hizmetler Ve Çocuk Esirgeme Kurumu Kanunu'nun 15. Maddesi) bahçelerde olması gereken mekanlar ve mekansal özelliklerle ilgili herhangi bir kriter bulunmamaktadır. Bu konudaki eksiklikleri ortaya koyarak çözüm getirmeyi amaçlaması bu çalışmanın özgün yanıdır.

Çevresel memnuniyeti etkileyen fiziksel özellikler katılımcılar tarafından değerlendirilmiş ve çevresel memnuniyet düzeyine en çok etki eden özellikler tespit edilmiştir. Buna göre, huzurevi sakinlerinin değerlendirmeleri sonucunda çevresel memnuniyet düzeyini etkileyen fiziksel özelliklerin; konumsal özellikler, erişilebilirlik özellikleri ve tasarım özellikleri olduğu belirlenmiştir. Bunların içerisinden çevresel memnuniyet düzeyine en çok etki eden fiziksel özellik ise erişilebilirlik özelliği olmuştur. Ayrıca her bir huzurevinin erişilebilirlik özellikleri farklılık gösterdiğinden buna bağlı olarak kurumlarının erişilebilirlik özelliğinden duydukları memnuniyet düzeylerinin de farklılık gösterdiği tespit edilmiştir. Bunun dışında diğer iki fiziksel özellik bakımından ise; 
memnuniyet düzeyini en çok etkileyen ikinci özellik kurum bahçelerinin tasarım özellikleridir. Bahçelerdeki mekânların tasarımlarının gerek araştırmacı incelemesinde, gerekse katılımcıların değerlendirmeleri sonucunda farklılık gösterdiği ve yetersiz olduğu tespit edilmiştir. Konumsal özelliklere bakıldığında ise, araştırmacı tespitlerinde de benzer konumlarda yerleşmiş oldukları görülmüştür. Dolayısıyla konumsal özelliklerin çevresel memnuniyet düzeyini diğer iki özelliğe göre daha az etkilediği ve farklı huzurevlerine göre farklılık göstermediği tespit edilmiştir.

$\mathrm{Bu}$ sonuçlar doğrultusunda, huzurevleri bahçeleri tasarlanırken şu kriterlerin göz önünde bulundurulmasılyla, yaşlıların kurum bahçelerinden duydukları çevresel memnuniyet düzeyleri ve tercihleri artacaktır;

- Aile ve Sosyal Politikalar Bakanlığı, Engelli ve Yaşlı Hizmetleri Genel Müdürlüğünün, Huzurevleri ile huzurevi yaşlı bakım ve rehabilitasyon merkezleri yönetmeliğinde bahçelerle ilgili bir madde eklenmesi, bu maddede akademik çalışmalarla elde edilen sonuçlara göre bahçe tasarımı, mekanlar ve mekansal özellikler açısından kriterlerin olması gereklidir.

- Bu çalışma kapsamında araştırmaya dahil edilen huzurevlerinde halihazırda peyzaj projelerinin olmadığı tespit edilmiştir. Ancak hemen hepsinde yapıya ait mimari proje vardır. Her birinin yapısal mimari projelerinin yanında yapısal ve bitkisel peyzaj projelerinin olması ve uygulanmış olması gerekmektedir. Çünkü yaşlılar kurum binasında geçirdikleri vakit kadar bina dışında da vakit geçirmektedirler.

- Kurumların bina ve bahçeleri, ölçüleri açısından incelendiğinde; bir oranın söz konusu olmadığı tespit edilmiştir. Oysa kapalı birimlerin toplam alanı göz önüne alınarak açık mekânların ne kadar büyüklükte olması gerektiği tespit edilmeli ve yönetmelikte ilgili maddede bu konuda yapılacak farklı bilimsel çalışmalarla da; bu görüşün desteklenmesi beklenmektedir.

- Kurum bahçelerinin fiziksel özellikleri, konumsal, erişilebilirlik ve tasarım özellikleridir. Konumsal özellikler açısından memnuniyete bakıldığında kırsal ya da kentsel ya da diğer alt faktörleri açısından yaşlılar görüşlerini belirtmek istememiştir. Sonuçların 3 ve 3'e yakın değerler alması bu şekilde yorumlanabilir. Kentsel bölgede konumlanan Trabzon Köşk Huzurevi ve Ordu Ahmet Cemal Mağden Huzurevlerinde kısmen de olsa konumsal özelliklerinden memnuniyet duyulduğu tespit edilmiştir. $\mathrm{O}$ halde bu sonuçlara göre, huzurevlerinin kentsel bölgelerde konumlandırılması ve çevrelerindeki işlev alanlarının çok çeşitli olması yaşlıların çevresel memnuniyet düzeyini artıracaktır.

- Diğer bir fiziksel özellik olan erişilebilirlik özelliği şehir merkezine uzaklık, şehirden kuruma erişim ve kurum bahçesi içindeki erişim şeklinde değerlendirilmiştir. Kent merkezine en yakın ve kuruma ulaşan bir dolmuş hattı olan huzurevleri erişilebilirlik açısından diğerlerine göre yüksek değerler almıştır. Dolayısıyla huzurevlerinde kalan yaşlıların kurumun erişilebilirlik özelliklerinden memnuniyet duyması için kurumun kent merkezine yakın ve bir toplu taşıma hattına yakın olması önerilmektedir.

- Kurum bahçelerinin peyzaj tasarım özelliklerinin yaşlılar tarafından değerlendirilmesi sonucunda çok düşük düzeylerde memnuniyet ve görüş bildirmek istemeyenler olmuştur. Tasarım özelliklerinin alt faktörleri, bahçelerdeki yapısal, bitkisel peyzaj elemanları, sirkülasyon elemanları ve içerdiği mekanlardır. Bu bakımdan yapısal ve bitkisel elemanlar ve içerdiği mekânlar açısından en zengin olan huzurevleri Ordu Ahmet Cemal Mağden ve Trabzon Köşk Huzurevlerinde memnuniyet düzeyi daha yüksekken sadece iki bitki türü ve toprak zemine sahip Murgul Huzurevinde en düşük çıkmıştır. Huzurevi bahçelerinde yaşlılar için etkinlikler içeren mekanlar ve bu mekanlarda uygun donatılar ve bitkiler olmalı aynı zamanda bu etkinlik alanlarına ve donatılara ulaşan uygun zeminli ve eğimli sirkülasyon elemanları olmalıdır. Farklı türde bitkilere yer vermenin yanında bu bitkilerin arasında yürüyebilecekleri gezinti yolları, gölgelerinde oturabilecekleri oturma birimleri olmalıdır.

Bu çalışmada Türkiye'de huzurevleri ile ilgili yapılan lisansüstü tezler, YÖK tez arama veritabanı kullanılarak araştırılmıştır. Huzurevleri ile ilgili çalışmalar yapan ilgili başlıca bilim dalları; tıp, sosyoloji, geriatri, hemşirelik, psikoloji, fizyoterapi, eczacılık, halk sağlığı, turizm, spor, antropoloji, din, ev ekonomisi ve mimarlıktır. Tüm bu bilim dallarında yapılan "huzurevleri” konulu lisansüstü tez çalışmaları arasında peyzaj mimarlı̆̆ meslek disiplinince yapılan çalışmaların oranı \%1,12'dir. Yaşlılık gibi huzurevleri konusu da peyzaj mimarlığı alanında daha fazla çalışılması gereken konulardan biridir. Bu bağlamda; yaşlılar ve huzurevlerini peyzaj mimarlığı alanında birlikte ele alarak araştırmanın, oldukça önemli olduğu düşüncesiyle yapılan bu çalışmanın benzer alanlarda yapılacak çalışmalara örnek oluşturması beklenmektedir. 


\section{Not}

Bu çalışma, ilk yazar tarafından KTÜ Fen Bilimleri Enstitüsü, Peyzaj Mimarlığı Anabilim Dalı Programı'nda tamamlanmış olan“Huzurevi Bahçelerindeki Çevresel Memnuniyet Düzeylerinin Ve Çevresel Tercihlerinin Belirlenmesi Üzerine Bir Araştirma” isimli tezden üretilerek hazırlanmıştır.

\section{References}

1. Alshuwaikhat HM, Abubakar I. (2008). An integrated approach to achieving campus sustainability: Assessment of the current campus environmental management practices. Journal of Cleaner Production, 16, 1777- 1785.

2. Altay V (2012). Mustafa Kemal Üniversitesi Tayfur Ata Sökmen Kampüsü (Hatay)'nün süs bitkileri. Karadeniz Fen Bilimleri Dergisi Cilt: 2, Sayı: 6.

3. Anonymous (2017). N. K. Ü. Construction and Technical Department, Oral interview.

4. Anşin R, Terzioğlu S (1998). Exotic Tree and Shrubs of The Eastern Black Sea Region. Karadeniz Technical Universitey Press No: 192, Trabzon, 132 pp.

5. Bernatzky A (1983). The Effect of Trees on The Urban Climate, Trees in the 21 st Century. Oxford.

6. Bolund P, Hunhammar S (1999). Ecosystem services in urban areas. Ecological Economics, 29, 293301.

7. Breuste J.H. (2004). Decision making, planning and design for the conservation of indigenous vegetation within urban development. Landscape and Urban Planning, No: 68.

8. Brickell C (1996). A- Z Encyclopedia of Garden Plants. The Royal Horticultural Society, Dorling Kindersley Limited, London, 1080 pp.

9. Çelem H, Şahin Ş, Güneş G (1997). Road Forestation in Cities, ISBN: 975945560 9, Ankara.

10. Deveci M, Özbucak TB, Demirkol G (2012). Ordu Üniversitesi kampüs alanı florasının tespiti. Akademik Ziraat Dergisi Cilt: 1, Say1: 2.

11. Düzenli T., Mumcu S., Işık Ö. B. (2016). Design of campus open space depending on the needs of the young people. İnönü University Journal of Art and Design, 6 (13), 121- 130.

12. Ertekin M, Çorbacı ÖL (2010). Landscape design in university (Karabük University Landscape Project Example). Journal of Kastamonu University Forestry Faculty, 1, 55- 67.

13. Fakir H, Babalık AA, Karatepe Y (2009). Süleyman Demirel Üniversitesi Kampüsü’nün doğal bitki türleri (Isparta-Türkiye). Süleyman Demirel Üniversitesi Fen Bilimleri Enstitüsü Dergisi, Cilt: 13, Say1: 1.

14. Gumprecht B (2007). The campus as a public space in the American college town. Journal of Historical Geography, 33, 72- 103.

15. Kahraman A, Onder M, Ceyhan E (2012). The importance of bioconservation and biodiversity in Turkey, International Journal of Bioscience, Biochemistry and Bioinformatics, Vol. 2, No. 2.

16. Karakaş B (1999). Physical Development Plan Preparation Process of university campuses and investigation of Bartın Forestry Faculty, Zonguldak Karaelmas University Institue of Natural and Applied Sciences, Master's Thesis, Bartın.

17. Karaşah B, Sarı D, Yaman YK (2016). Bir yerleşke peyzaj tasarımı: Artvin Çoruh Üniversitesi Şehir Yerleşkesi, Erciyes Üniversitesi Fen Bilimleri Enstitüsü Dergisi Cilt: 32, Sayı: 3.

18. Korkut AB, Şişman EE, Özyavuz M (2010). Landscape Architecture, Verda Publishing, ISBN: 97860558838109.

19. Lau SSY, Yang F (2009). Introducing healing gardens into a compact university campus: Design natural space to create healty and sustainable campuses. Landscape Research, 34:1, 55- 81.

20. McFarland AL, Waliczek TM, Zajicek JM (2008). The relationship between student use of campus green spaces and perceptions of quality of life. Horticulture Technology, 18 (2) 232- 238.

21. Nugay ÖZ, Duran A, Doğan B (2007). Kırıkkale Üniversitesi kampüs florası. S.Ü. Fen Ed. Fak. Fen Dergisi Sayı: 30.

22. Symonds WD, Chelimsky SV (1958). The Tree İdentification Book. William Morrow and Company, New York, 272 pp.

23. Symonds WD, Merwin AW (1963). The Shrub İdentification Book. William Morrow and Company, New York, 379 pp.

24. Ulrich R (1984). View through a window may influence recovery from surgery. Science, 224, 420- 421. 
25. Ünal O, Gökçeoğlu M (2003). Akdeniz Üniversitesi kampus florası (Antalya-Türkiye). Akdeniz Üniversitesi Ziraat Fakültesi Dergisi, Cilt: 16, Sayı: 2.

26. Yılmaz H, Irmak MA (2004). Evaluation of plant material in open green areas of Erzurum city. Journal of Ecology, 13 (52), 9-16.

27. Yılmaz S (2015). Landscape design of a campus outdoor space: Süleyman Demirel University. Kastamonu University Journal of Forestry Faculty, 15 (2), 297- 307.

28. Yücel E (2005). Trees and Shrubs I. Eskişehir, ISBN 975- 93746- 2- 5, 301.ü, Orman Endüstri Mühendisliği Anabilim Dalı, Bartın, 143s. 
